\title{
Unhappy Bodies: The Frigid Woman in The Second Sex
}

\author{
How does a pile of rags the machinist wiped his hands on \\ feel in its cupboard, hour after hour? \\ Each day during the heat-wave \\ they took the temperature of the haymow. \\ I huddled fugitive \\ In the warm sweet simmer of the hay \\ muttering: Come. \\ ADRIENNE RICH ${ }^{1}$
}

We may find it irritating that The Second Sex was once marketed like a semidirty book, with a naked woman crouching on the cover, or we may find it merely funny; but the characterization of it as a book about sex is not exactly wrong. Readers who have studied only excerpts may find this a surprising claim. Many women's studies classes tend to assign just the introduction, for sound reasons: feminist theory since the 1960 s could be described without huge exaggeration as a series of commentaries on that introduction, even when subsequent theorists have been only hazily aware of what Beauvoir's text actually says. But even in Parshley's truncated version, the book is 724 pages long, and the opening theoretical moves that have been subject to such intense exegesis are supported and deepened by a very wide range of empirical evidence, concrete and detailed analysis, and phenomenological exploration of women's experiences under patriarchy, including the private (or as the jacket copy puts it, "intimate") experience of the female body and how it feels, from the inside out.

Still, anyone who purchased The Second Sex hoping for a dreamy afternoon in the company of the woman pictured on the cover was in for a disappointment, because the sex in The Second Sex is mostly bad sex. As a monumental catalogue of female sexual discontent, it is far from anomalous in Beauvoir's œuvre. The first manuscript she ever completed and offered to a publisher, a short "novel in stories" that was later renamed Quand prime le spirituel, was an unsentimental, demystifying exploration of young women's sexual frustration,

1 Rich, "The Phenomenology of Anger," 165. 
with a firm stance against the suffocating chastities of a Catholic milieu; ${ }^{2}$ L'invitée, Le sang des autres, and most especially Les mandarins offered unsentimental fictional accounts of sexual dissatisfaction and its ravages; her late literary works, La femme rompue and Les belles images, deal candidly with what might be called the sexual silencing of the French wife; she returned to the question in her last autobiographical volume, La cérémonie des adieux. Commentators have often focused on themes of masochism and jealousy, but a broader discussion of sexual dysphoria in Beauvoir's fiction would have to include the difficulties young people have discovering and expressing their sexuality; the problems women have interacting with comparatively undersexed men; the unsatisfactory nature of planned, deliberate sex. Her novels draw on both French and American modernist techniques to describe sex from a woman's point of view in a dispassionately concrete way that remains startling, even today.

"Tell me what you feel?" he said. "Tell me." I remained mute. Inside me, I sensed a presence without really feeling it, as you sense a dentist's steel tool against a swollen gum. "Do you like it? I want you to like it." His voice sounded vexed, demanded an accounting. "You don't? That's all rightthe night is long." ... I unclenched my teeth.... ${ }^{3}$

The Second Sex, too, importantly relies on fictional narrative to explore questions of women's sexual unpleasure, quoting at length from writers as disparate as Dorothy Parker, Colette, and Mauriac for accounts of women's lived sexual experience and, in the sections on "myth in five authors" - an inaugural moment for feminist literary criticism-demonstrating the willful male domination that underlies descriptions of the sex act in such apparently different writers as the ultra-Catholic Claudel and the would-be modernist iconoclast D.H. Lawrence.

But Beauvoir also makes serious use of scientific, expert "findings" about female sexuality, and frequently refers to something called "frigidity," a concept that second-wave feminism would take great pains to discredit. Her discussion

2 Written between 1935 and 1937, the novel, originally called Primauté du spirituel, was refused by publishers and only appeared in 1979 .

3 'Dis-moi ce que tu sens? dis-le-moi.' Je restai muette. Je devinais une présence en moi, sans vraiment la sentir, comme on s'étonne de l'acier du dentiste dans une gencive engourdie. 'Astu du plaisir? Je veux que tu aies du plaisir.' Sa voix s'irritait, elle exigeait des comptes: ‘Tu n'en as pas? ça ne fait rien: la nuit est longue"' (Les mandarins, 1:118-21). For fuller discussion, see Altman, "Before We Said 'We' (and after): Bad Sex and Personal Politics in Doris Lessing and Simone de Beauvoir." 
leans heavily on the rather bizarre work of early psychoanalyst and sexologist Wilhelm Stekel, which has fallen into disfavor. So "frigidity" seems a good place to begin my exploration of what in this text is "dated" and what may still be of use. But although this chapter will look at what seems to be an anomalous, or even weird area in her work, something she did that "we wouldn't do now," my attempt to figure out what she was doing starts from the assumption that she knew what she was doing, that her choices were not accidents, that her text is coherent and marshals evidence toward a unified argument. I think that if readers, from the earliest reviewers to today, have not always found such coherence, it is often because they were missing information that would help them understand the context, or unduly swayed by later political commitments of their own, or possibly both. (Whether we agree with the overall argument, or find the examples and analysis convincing, is another matter.)

But when I say The Second Sex is, indeed, a book about "sex," what do I mean by "sex"? There's been so much subsequent work done on the proper parameters of that term: where "sex" stops and "gender" begins, which constructs the other, how to think sexual difference beyond the man/woman binary, and so on. This is far from irrelevant to the study of Beauvoir, or rather, what Beauvoir wrote is not irrelevant to it, particularly since she can be invoked on many sides of many debates. Most obviously, while the term "gender" was not available to her, what would later be called "social construction" theory certainly traces back to her foundational claim that "one is not born a woman, one becomes a woman." 4 And there's more to explore: the chapter on biology, which has often seemed quite strange, deserves to be revisited in the light of postbinary, perhaps even post-human, ways of thinking about sex and gender, especially since much of the relevant material was missing or garbled in the old translation. ${ }^{5}$

But none of that is what I'm going to talk about here. When I say "sex" in what follows, I mean roughly, what people do in bed, and how they feel and think about that. When I say "sexuality," I mean the whole complex of emotions

4 "On ne naît pas femme: on le devient." The translation of this famous sentence remains controversial. Parshley had "one is not born, but rather becomes, a woman"; the new translators have been criticized for dropping his indefinite article. In my own view, the French authorizes a number of plausible and correct approaches, and what people do is a matter of how they interpret Beauvoir's overall intention, rather than how expert their French may be. See Altman, "The Grand Rectification." But see Moi, "The Adulteress Wife," for a different view. The issue is exhaustively investigated in the 2017 anthology, "On ne nait pas femme, on le devient: The Life of a Sentence," edited by Bonnie Mann and Martina Ferrari.

5 For relevant passages and discussion, see Altman, "Beauvoir, Hegel, War"; Elizabeth Fallaize, "A Saraband of Imagery"; Judith Butler, "Sex and Gender in Simone de Beauvoir's Second Sex." 
and ideas a person brings to that activity, based more or less on what they've learned from their culture. And when I say "bad sex," I mean quite literally what happens when people engage in that activity and it doesn't go well, it isn't satisfying to one or both of them, in ways that may have both causes and consequences that stretch beyond that actual bed on that particular day. Flatfooted as this may sound, my contention is that Beauvoir throughout her œuvre was profoundly interested in sex, and in bad sex, understood in just this way, and that (both as readers of Beauvoir and as feminists) we should be, too.

A fancier way to say this is that Beauvoir was interested in giving women full human subjectivity; that this importantly included sexual subjectivity; and that times when sex goes badly have a potential for unusual lucidity about what female sexual subjectivity is, and also what it could be.

Philosopher Sandra Bartky once observed that "[a]norexia nervosa, which has now assumed epidemic proportions, is to women of the late twentieth century what hysteria was to women of an earlier day: the crystallization in a pathological form of a widespread cultural obsession." ${ }^{\prime 6}$ Historically locatable between the hysteric and the anorexic, both of whom Beauvoir also discusses, the "frigid" woman, and the sexually miserable woman more generally, fulfills some of the same function in her work: as a hypostatized, overexaggerated, larger-than-life figure for the situation of women in her time, for the "normal female" (that monster) as society constructs her and then demonizes her. Such figures, and the moral panics that grow up around them, have been reclaimed by feminists in two (opposite) ways: as evidence of the damage culture does to women, and, more controversially perhaps, as figures for resistance, pointing to a possible way out. ${ }^{7}$

Of course the "frigid woman" can't be that for us now. But the search for a usable feminist past has led me to notice how feminism as we know it was born from a discourse of women's dissatisfaction with their situation that importantly included labelling and cataloguing, naming, sexual dissatisfaction. ${ }^{8}$

6 Bartky, Femininity and Domination: Studies in the Phenomenology of Oppression, 66.

7 For reclamation of the figure of the hysterical woman, see for example Hélène Cixous and Catherine Clément, La jeune née. For an argument that parallels mine, see Suzanne Cataldi's excellent "Sexuality Situated: Beauvoir on Frigidity." Cataldi writes: "Rather than viewing [frigidity] as an instance of female passivity or an organic incapacity, [Beauvoir] constructs it as a symbolic use that women may make of their bodies.... If ... we view frigidity as a means or method of resistance, or a harm that women suffer in a culturally oppressive or sexist environment, we will be more apt to notice the agency behind the passivity and the assumptions implicit in labeling a woman 'frigid"” (70). See also Raquelle K. Bostow, "Frigidity According to Beauvoir: Le deuxième sexe as a Precursor to Second Wave French Feminism."

8 See Altman, "Beyond Trashiness: The Sexual Language of 7os Feminist Fiction," and Alix Kates Shulman, "Sex and Power: Sexual Bases of Radical Feminism." 
Often articulated in popular novels rather than as "feminist theory," this discourse overlapped problematically with discourses that were not feminist, some that came to be seen as anti-feminist. This is hardly unusual. Feminism has always had, and has today, a complex and uneasy relationship with other culturally available discourses on gender and sexuality: biological discourses; religious ones (particularly in the nineteenth century, when some, though not all, activists for suffrage drew on arguments that women were morally superior to men); discourses about the "new woman" or "free woman" in the 188 os, the 1920 , the "sexual revolution" of the 196os; psychoanalytic approaches; love stories... Today it seems particularly difficult to disentangle feminism from various inspirational and therapeutic discourses we see in popular self-help texts and social formations. For instance, the "recovery movement" (of which Alcoholics Anonymous is the best-known example) shares much of its "method" with early feminist consciousness-raising (truth-telling, safe space, going around the room), but moves participants toward a collective acknowledgment of their powerlessness rather than a resolve to take collective action for social change. ${ }^{9}$ We're also seeing a revaluing of (retreat to) the domestic sphere (crafts, do-it-yourself, local food, attachment parenting, etc.) which seems to have a simultaneously symbiotic and antagonistic relationship to feminism, and the marshalling of a feminist (or "postfeminist") rhetoric of "self-empowerment" (and "health") around the never-ending pursuit of the impossibly perfect body. None of this can be dismissed as naïve: as Alison Winch observes about "body talk," "critique and complicity are simultaneous." ${ }^{10}$ Perhaps it will help to remember that earlier generations of feminists had discourse trouble also, and to look at how they worked within it, worked with it, and "worked" it.

A Passion for Frigidity?

In La force de l'âge (The Prime of Life), the second volume of Beauvoir's autobiography, one sentence jumps out from a long section where Beauvoir carefully

$9 \quad$ See Elayne Rapping, The Culture of Recovery: Making Sense of the Self-Help Movement in Women's Lives, and Wendy Kaminer, I'm Dysfunctional, You're Dysfunctional: The Recovery Movement and Other Self-Help Fashions.

10 See Emily Matchar, Homeward Bound: Why Women Are Embracing the New Domesticity; Alison Winch, Girlfriends and Postfeminist Sisterhood. The phrase I quote comes from a talk Winch gave at Oxford in 2014. Her work is particularly concerned with the way women's bodies, and women's "correct" participation in neo-liberal (over)consumption, are policed by other women deploying the affects of "sisterhood," a process she has named "the gynaeopticon." 
records what she and Sartre were reading and studying, what films and music they enjoyed, etc., in the mid-193os, before they wrote the books that would make them famous: "We became passionate about Stekel's The Frigid Woman, because he was proposing a psychoanalysis which rejected the notion of the unconscious."11

Four things (at least) seem odd about this sentence today. Just on the surface, the conjunction of "frigid" and "passionate" feels paradoxical, even a bit louche: one could almost translate, "we fell in love with the frigid woman"... Second, we think of "the unconscious" as the foundational concept of psychoanalysis, as Freud's great contribution to modern thought, as what distinguishes psychoanalysis from other methods of therapeutic intervention and other forms of intellectual investigation (such as biology or analytic philosophy). So isn't the idea of a psychoanalysis without the unconscious theoretically incoherent?

Third, "frigidity" is a word seldom heard nowadays, and certainly not from feminists. It sounds like an accusation, or a confession, of terrible, intimate failure, like a strange relic of a bygone era when bad shrinks made good women stay in terrible marriages, now happily banished along with iron maiden girdles and "sure, she's Phi Beta Kappa, but can she type?" It sounds like something you'd hear as you got out of the car at the end of a very bad date-but the car in question is an old gold Chevy with tailfins. Where men's sexual problems are still very much with us (just try to watch a football game without hearing about them), women's difficulties with pleasure seem to have gone underground, and "frigidity" as such has disappeared. In more popular media, specifically sexual problems women have are talked about using other words: for instance, they may be framed as problems of "miscommunication."12 Meanwhile, chemical and surgical "remedies" are marketed for something called

11 "Nous nous passionnâmes pour La femme frigide de Stekel parce qu'il proposait une psychanalyse qui rejetait la notion d'inconscient" (La force de l'âge [hereinafter FA], 328). The year is 1936 .

When quoting from Beauvoir, I have translated the title of Stekel's book as The Frigid Woman, which reflects the title of the French translation she read (La femme frigide), (and incidentally gives a more accurate sense of the book's contents than the original German title, Die Geschlechtskälte der Frau). French quotations from Stekel in Le deuxième sexe are given here exactly as Beauvoir gives them there, and translated by me from her quotation. My own readings of his work use the title of the English-language edition, Frigidity in Woman.

12 See Lisa Bland and Rusty Barrett, “'Stick your (adj.) (noun) in my (adj. noun)!: Teaching Women to Talk Dirty" for discussion of 199os sexual self-help books. For general discussion of "miscommunication" see Deborah Cameron, Verbal Hygiene. 


\section{"female sexual dysfunction." So it's not that everyone is happy in bed! But the frigid woman as a monstrous personality type seems to be gone. ${ }^{13}$ \\ The banishing of "frigidity" as a weapon to be used against women was an explicitly-framed demand of 1970 os feminism..$^{14}$ In the United States, the locus}

13 When I first began working on what became this chapter, I wrote rather blithely that "while in the 1950s a woman diagnosed with this 'disorder' could be hospitalized and given shock treatments against her will, now you can't even get insurance coverage for it, because the DSM (Diagnostic and Statistical Manual) doesn't list it." Many years on from that "now," the situation looks murkier: it would require a whole new paper to sort through the proliferation of diagnoses currently available, not to say marketed, to women who don't find the kind of sex they are having to be one hundred percent satisfying. Increasingly this is conceived of as an organic, or semiorganic, "dysfunction" or "disorder" (the machine has broken down, but we can fix it). A partial survey: The DSM-IV (1994) included "hypoactive sexual disorder" and "sexual aversion disorder" (gender-neutral), and also "female orgasmic disorder (FOD, formerly inhibited female orgasm)," about which it explained, "[w]omen exhibit wide variability in the type or intensity of stimulation that triggers orgasm. The diagnosis of FOD should be based on the clinician's judgment that the woman's orgasmic capacity is less than would be reasonable for her age, sexual experience, and the amount of sexual stimulation she receives. The disturbance must cause marked distress or interpersonal difficulty.... No association has been found between specific patterns of personality traits or psychopathology and orgasmic dysfunction in females" (505-6). They distinguished this from female sexual arousal disorder, dyspareunia, and vaginismus. The $D S M-5$ (2013) lists ten possibilities, of which three (female orgasmic disorder, female sexual interest/arousal disorder, and genito-pelvic pain/ penetration disorder) would seem to apply to women only.

The $D S M$ itself, however, is currently in disrepute, not least because of its ties to Big Pharma. See Robin Rosenberg, "Abnormal is the New Normal: Why Will Half of the U.S. Population Have a Diagnosable Mental Disorder?" Activists who identify as asexuals have also called the $D S M-5$ into question, by analogy to successful challenges raised over time by those who wanted to remove "homosexuality" and "transsexuality" from the list of pathologies and disorders. Meanwhile, scientists admit a lack of consensus about the taxonomies of female unpleasure. See R. Rosen et al., "The Female Sexual Function Index (FSFI): A Multidimensional Report Instrument for the Assessment of Female Sexual Function." The authors note that their research was supported by Zonagen Inc. and Bayer AG. But lack of consensus has not prevented the explosive development of an industry dedicated to uncovering and expensively treating it, as Liz Canner's film Orgasm Inc. documents in distressing detail. See also Carole Tavris, The Mismeasure of Woman, and Leonore Tiefer, Sex is Not a Natural Act and Other Essays and "Female Sexual Dysfunction: A Case of Disease Mongering and Activist Resistance." (It may be worth mentioning that the idea of surgical "remedies" to make possible vaginal orgasm dates back to Freud's student and patron Marie Bonaparte, and is not new.)

"Erectile dysfunction" and "low T" are also a shift from the vocabulary of "impotence," and perhaps it is a good sign if we no longer expect a man to be powerful and a woman to be simply warm. Concerns remain.

14 See Jane Gerhard, "Revisiting 'The Myth of the Vaginal Orgasm': The Female Orgasm in American Sexual Thought and Second Wave Feminism"; Beatrix Campbell, "A Feminist 
classicus for this point is Anne Koedt's "The Myth of the Vaginal Orgasm" (1968); older readers may also recall a poster from British Women's Liberation (where did I put that?) which reads (emphasis added):

because women's work is never done and is underpaid or unpaid or boring or repetitious and we're the first to get the sack and what we look like is more important than what we do and if we get raped it's our fault and if we get bashed we must have provoked it and if we raise our voices we're nagging and if we enjoy sex we're nymphos and if we don't we're frigid and if we love women it's because we can't get a man and if we ask our doctor too many questions we're neurotic and/or pushy and if we expect community care for our children we're selfish and if we stand up for our rights we're aggressive and unfeminine and if we don't we're typical weak females and if we get married we're out to trap a man and if we don't we're unnatural and because we still can't get adequate safe contraceptives but men can walk on the moon and if we can't cope or don't want a pregnancy we're made to feel guilty about abortion and for these and lots of other reasons we are part of the women's liberation movement. ${ }^{15}$

A depressing amount of this is still relevant, but at least one feminist demand seems to have succeeded: when teaching The Second Sex or The Golden Notebook, I often find myself having to explain what the unfamiliar word "frigidity" even meant. This is not at all to say that the current state of sexual discourse may not be equally bad for women; but at least the ground for debate has shifted.

Fourth and finally, the very presence of Stekel's name in Beauvoir's report becomes bizarre, once one knows who he was. Fortunately, few do, so I'll need to introduce him at some length: but without at all meaning to suggest that his work is a rich, untapped vein for feminist theory. Au contraire.

\section{2 \\ Who Was Wilhelm Stekel?}

Wilhelm Stekel (1868-1940) was a minor member of Freud's circle in Vienna, an "early adopter" and avid propagandist. We think of psychoanalysis as Freud,

Sexual Politics: Now You See It, Now You Don't"; Carole Vance, "Introduction," Pleasure and Danger: Exploring Female Sexuality.

15 Joyce Stevens, "Because We're Women." First published as a broadsheet for International Women's Day, Sydney, 1975. 
Jung, and Adler, but at the very beginning of the Vienna Psychoanalytic Society it was actually Freud, Adler, and Stekel. In his rather florid Autobiography, Stekel says, "I was the apostle of Freud who was my Christ!" but Freud seems soon to have cast him instead as Judas: he was tossed out of the Vienna Psychoanalytic Society for siding at crucial moments with Adler and against Victor Tausk, but also because, even when one corrects for the customary ad hominem rancor of that group's internal politics, he appears to have been a repulsive individual. Jung called him "a nuisance to psychoanalysis": Freud himself referred to Stekel as "morally insane," "an imbecile [schwachsinnig]."16 Even the colleague who edited and introduced his posthumously published autobiography calls attention to "his unresolved narcissism, his overcompensated feelings of inadequacy."17 Others accused him of distortions, plagiarism, fabricating his case records, and general "dirty-mindedness." Stekel was a nuisance because the unfriendly caricature of Freudians drawn by narrow-minded social conservatives was, in his case, uncomfortably close to the truth.

Beauvoir may or may not have known this, and it needn't matter. But Stekel's published work, including this hugely popular and influential book, displays the same instability and untrustworthiness that make him figure in the history of psychoanalysis as a butt and a buffoon. His statements about women veer wildly from the progressive to the hidebound and back again. Two apparent principles of selection emerge in his case histories: to include as much titillating material as he can, and second, to show the doctor (himself) in the most heroic manner possible, in contrast to his female patients who (to borrow Lacan's phrase) "don't know what they are saying." His tone brings him closer to Dr. David Reuben's cheerily heterosexist Any Woman Can than to a serious work of philosophy and politics. ${ }^{18}$ Both Paul Roazen and Toril Moi have called his books "pornographic,"19 and while this is a word I use only with trepidation, here it seems appropriate to name a literary genre which features repetition, redundancy, and excessive detail in sexual scenes, while the narrative or theoretical presentation which strings them together and "justifies" their inclusion

16 Jaap Bos and Leendert Groenendijk, "The Art of Imitation: Wilhelm Stekel's Lehrjahre”; Paul Roazen, Freud and His Followers; Peter Gay, Freud: A Life for Our Time; Vincent Brome, Freud and His Early Circle; Ernest Jones, The Life and Work of Sigmund Freud.

17 The Autobiography of Wilhelm Stekel: Or, the Life Story of a Pioneering Psychoanalyst, 13.

18 See Altman, "Everything They Always Wanted You to Know: The Ideology of Popular Sex Literature."

19 Moi, Making of an Intellectual Woman. While I cannot agree with some of Moi's more psychoanalytically-based readings, I've found her overall approach both provocative and sensible. Her (brief) discussion of Stekel occurs on pages 200 and $283-84$. 
comes to seem a flimsy, perfunctory pretext. ${ }^{20}$ "Melodramatic" also seems apt. Even within the contested genre of sexology, vulnerable since its inception to charges of sensationalism, exploitation, and self-interest, this fellow stands out as a questionable figure, and not unfairly so. ${ }^{21}$

Frigidity in Woman is dominated by voluminous quotations from case materials, which in a certain way give voice to "women" speaking openly about their sexual experiences. But these stories are framed by a profound distrust of what Stekel calls the "prevaricating woman," making his book a direct ancestor of The Sexually Adequate Female (1953) by Frank S. Caprio, M.D. Caprio's unimaginably awful bestseller is really about the sexually inadequate, or as he puts it "sexually incompetent," woman and what she must do to improve herself and save her marriage. He actually goes one step further than Stekel: since for him, the only orgasm that counts is vaginal orgasm, he feels able to speak for example of "the frigid nymphomaniac." Frigidity, says Caprio, causes infidelity, alcoholism, and worst of all, divorce. His is the book Anne Koedt will take as her target, the book Norman Mailer will turn to in The Prisoner of Sex (1971) to authorize his assertion that whatever feminists may say, he knows he has given "his" woman an earth-shattering orgasm. Caprio's other claim to fame is $\mathrm{Fe}$ male Homosexuality (1954), authoritative for many years, and singled out by Jonathan Katz for its homophobic, destructive insistence on "heterosexual adjustment."22 Both books are written firmly under the influence of Stekel.

And yet, when Beauvoir said she and Sartre had been "passionate" about Frigidity in Woman she was not exaggerating: both took it seriously in formulating (rather differently) the philosophical problem of the body, and so did Maurice Merleau-Ponty. ${ }^{23}$ My overarching question is why, or (to put it more plainly) how could she? But first I must show how.

$20 \quad$ See Stephen Marcus, The Other Victorians, for the classic discussion.

21 I'm using "sexology" rather inclusively here (following Sylvie Chaperon's example in Les origines de la sexologie, 1850-1900) to cover any form of writing about sexuality that makes a strong claim to scientific authority, whether medical, quasi-medical, or extra-medical. In Frigidity: An Intellectual History, Peter Cryle and Alison Moore trace the interpenetration of middlebrow novels and medical popularizations in France more broadly, and earlier, back to the late nineteenth-century "roman de mœurs": see 6, 108, and 120-21, and chapter 5 , "The Wedding Night" (132-60).

22 See Jonathan Ned Katz, Gay/Lesbian Almanac and Gay American History for much interesting material on both Stekel and Caprio. For instance, Katz found that a number of Caprio's "cases" were lifted from True Confessions magazine, another plagiarized from Krafft-Ebing.

23 See Cataldi, "Sexuality Situated," 75-79, and Le Dœuff, Hipparchia's Choice, 62-72 and 113-16, for good discussions of how Beauvoir's concept of frigidity differs from Sartre's. Cataldi and Le Dœuff both mention Stekel as a source Beauvoir and Sartre use very 
Stekel's name appears in The Second Sex sixty-three times. Nine times, Beauvoir quotes or paraphrases a view he holds in order to agree with it; once (the only instance from volume 1 ) she partly agrees and partly disagrees; two are passing references. The vast majority (fifty-one) are drawn from the descriptive case studies in Frigidity in Woman. Of these cases, eleven are quoted or cited briefly (a sentence or two), thirty-two take at least an indented paragraph, four take up at least half a page in the Gallimard Folio edition, and four are longer than a page. For purposes of comparison, Sartre's name appears ten times, and her longest quotation from him is two sentences long. Obviously I'm not arguing that Stekel is a greater influence on Beauvoir than Sartre, just that there's enough here to make it surprising that Stekel isn't more discussed in the secondary literature.

However, readers who've worked, or worked mainly, from H.M. Parshley's English translation can be pardoned for wondering whether I'm over-reacting. Of Beauvoir's case citations, Parshley entirely omits five; he makes minor cuts in seven of her quotations; but his most usual procedure is to substitute a tame paraphrase of his own, usually a sentence or two. He does this with two of the four huge quotations, and with all four of the quotations that are between half a page and a page in length. (He also does this for two of Stekel's statements

differently, to the point where, as Le Dœuff notes, "one wonders if [Beauvoir] and Sartre had read the same book" (65); but neither Cataldi nor Le Dœuff historicizes "frigidity," as I am attempting to do here.

The independence of Beauvoir's thought from Sartre's, on this and very many crucial points, has now been sufficiently demonstrated that I feel no need to dwell on it (or him) here: those interested should consult Le Dœuff's book, Simons, Beauvoir and The Second Sex, and Christine Daigle and Jacob Golumb, Beauvoir and Sartre: The Riddle of Influence, for a rich range of interpretations. Whether one wants to grant Beauvoir intellectual priority and ownership of ideas Sartre then "stole," or see joint development of ideas, or continue to distinguish Beauvoir's ideas as better than Sartre's, it is clearly no longer possible to blame what's "wrong" (or, for that matter, what's right) with The Second Sex on Beauvoir's submissiveness to her boyfriend's view.

Merleau-Ponty's use of Stekel is also beyond the scope of this inquiry, but a summary by Dorothea Olkowski is not reassuring: "Merleau-Ponty seems to have little or nothing to say about sexual difference. Sexuality, he asserts, must lie in relations and attitudes and not in biology, in anatomical or physiological conditions. Yet he speaks of frigidity in exclusively feminine terms as always a refusal—of orgasm, of femininity, of sexuality—-that, in turn, is a rejection of the sexual partner and 'his' destiny, as if femininity were in service to 'his' destiny. There is certainly no mention of 'her' destiny, nor of the interval in which she acts.... What is missing in Merleau-Ponty's account is the woman's own affective temporality..." (Olkowski, “The End of Phenomenology: Bergson's Interval in Irigaray," 83). 
she cites in agreement.) If you look to Parshley's version for direct quotation of Stekel's own words, you'll find only three brief ones, three somewhat longer ones, and one huge one. Stekel's name, and his basic point, are still there, usually. What gets lost is his rather colorful voice, and the stylistic earmarks of the case history genre: "Miss M.G., 19 years old, was suddenly afflicted with a severe delirium.... Mrs. L.M., thirty-eight, tells me she is completely without feeling [insensible] with her husband.... Mrs. B.Z. was forty years old, had three children and had been married when she began...."24 Margaret Simons's classic 1983 article, "The Silencing of Simone de Beauvoir: Guess What's Missing from The Second Sex," noted that Parshley cut down the chapter on "The Married Woman" by almost half, and slashing at Stekel, who figures prominently there, was part of how Parshley did it. ${ }^{25}$

However, philological beancounting may show not that Stekel was a great and overlooked theoretical influence, but just the opposite. Beauvoir's most serious influences and agreements tend to dissolve into her own argument and are marked infrequently, unobtrusively, or sometimes not explicitly signaled at all (Sonia Kruks has showed this for Merleau-Ponty, Eva Lundgren-Gothlin for Hegel and Marx). ${ }^{26}$ By contrast, the names of Stekel and other sexological "authorities" seem to bead off like oil on water. Beauvoir's use of all sorts of authorities, sources, and influences should be understood as the opposite of slavish, and as somewhat different from the sort of "scholarly" marking of debts and disagreements to which Anglo-American academics are accustomed; so her "use" of Stekel could be compared to the way she silently "unhooks herself" (as Michèle Le Dœuff puts it) from Sartre, or as Toril Moi says, "swerves."27 And there are broad implications for what kind of an argument we take her to be making in The Second Sex. What kinds of truth claims is she making, and what

24 "Mlle. M.G. ..., âgée de dix-neuf ans fut subitement atteinte d'un délire aigu" (Le deuxième sexe [hereinafter $D S$ ] 2:169). "Mme. L.M..., trente-huit ans, mariée, me dit être complètement insensible auprès de son mari" ( $D S$ 2:418). "Mme. B.Z... avait quarante ans, trois enfants et derrière elle vingt ans de vie conjugale quand elle commença à penser" ( $D S$ 2:461).

25 See also Toril Moi, "While We Wait: The English Translation of The Second Sex," and Elizabeth Fallaize, "The Housewife's Destiny: Translating Simone de Beauvoir's 'The Married Woman."

26 Sonia Kruks, Situation and Human Existence: Freedom, Subjectivity and Society; Eva Lundgren-Gothlin, Sex \& Existence: Simone de Beauvoir's The Second Sex. Similar arguments can be made for other philosophers: see e.g. Emily Ann Parker, "Strange Freedom in Beauvoir and Nietzsche."

27 Michèle Le Doeuff, Hipparchia's Choice, 107; Toril Moi, Simone de Beauvoir: The Making of an Intellectual Woman, 143. See Nancy Bauer, Beauvoir, Philosophy, \& Feminism for a different, but quite compelling, formulation: Bauer describes Beauvoir as inventing an entirely new style of philosophical "appropriation." 
sort of purchase are they meant to have on the real world? Genre is not a purely academic quibble, or a pragmatic question about which shelf a work belongs on in the library or bookstore; genre matters because it signals a relationship, an implicit contract, between writer and reader. So how The Second Sex uses the generic conventions of sexological case history signals how it was meant to be read, and can help us see how women (and men) did read it before it became a work of Theory and a college text.

It is crucial to bear in mind the overall organization of The Second Sex, and especially its division into two volumes, which in France were first published separately, several months apart. Volume 1, "Les faits et les mythes" (Facts and Myths) begins with the theoretical introduction. The next section, labelled "Destin" (Destiny), disposes in three chapters of three types of arguments that have been used to "explain" women's supposed destiny in a deterministic way (biological, psychoanalytic, and "the point of view of historical materialism," which is to say, Marx and Engels). Then "Histoire" recounts the changing political and economic positioning of women from prehistory to the (then) present day. Finally "Mythes" analyses both grand collective primitive myths and then some examples from modern literature, pulling together a complex, contradictory, but ultimately unified story of how woman is situated as a dominated Other, by a combination of men's self-interest, women's complicity with it, and the social structures that come to solidify and embody male domination. Volume 2, titled "L'expérience vécue" (Lived Experience), begins again with its own brief introduction; it follows women through the life-cycle, then slides into individual chapters about specific types of women, but always understanding women's character as a dynamic response to her situation, which includes what we would now call her social location, but also includes the body, understood not as a static thing but as "our grasp upon the world, and a sketch for our projects." 28

Parshley unhelpfully rendered "L'expérience vécue" as "Women's Life Today," which loses its resonance as technical vocabulary for phenomenologists (see Moi, "While We Wait"). Also obscured is Beauvoir's focus, in this second volume, on life as women live it, live through it day after day, as changing subjects in a changing objective world; this is the dimension of "existence" and not of essentialized "Being," it is "lived" rather than (some reified notion of) "Life," as in The Meaning of Life. Like many of Parshley's alterations, the shift from "Lived Experience" to "Life Today" flattens out Beauvoir's account and brings it closer to a monolithic account of Woman than she intended. 
The first volume's unhooking of women from Woman, and the skepticism toward the Woman men invent and perpetuate, do, I'll argue, carry through and govern the second volume's somewhat looser discussion of "women and what they are like." The introduction to volume 2 begins with the paragraph about "women today" I quoted in my introduction, including the reminder that

[w]hen I use the words "woman" or "feminine," obviously I do not refer to any archetype, or any unchangeable essence; after most of my statements, one must understand [sous-entendre] "under present conditions of education and society." The point here is not to pronounce eternal truths, but to describe the common background from which every individual woman's existence arises. ${ }^{29}$

Beauvoir will make the same point in her conclusion (at the end of volume 2), and her philosophical language, in particular her account of "woman as Other" based on her rewriting of Hegel, is consistent throughout both volumes. But volume 2 includes much less explicit methodological self-reflection and almost no epistemological questioning or doubt, as if that had been established and cleared out of the way.

As I noted above, Beauvoir mentions Stekel only once in the first volume, and that mention is a cool one: it arises as part of her criticism of Freud and psychoanalysis more generally. Beauvoir's critique of Freud includes most of the arguments made by later feminists. His idea of female sexual development is simply a "calque" or belated extrapolation from male development, so the Electra complex doesn't make much sense, and his whole idea of sexuality is "flou," vague, because he never makes clear when he's talking about genitality and when he isn't. His concept of "resistance" makes it impossible to argue with him. He doesn't seem to know the difference between the penis, "this fragile stem of flesh," 30 and the phallus: men's access to power, freedom, activity in the wider world, which little girls might indeed envy, and why shouldn't they? His account is problematically ahistorical. ${ }^{31}$ He has an "ersatz de morale" (an ersatz ethics): ${ }^{32}$ his system is normalizing, substituting some ideal of "health"

\footnotetext{
$29 \quad D S_{2: 9}$.

$30 \quad$ "[C]ette fragile tige de chair" ( $D S$ 1:82).

31 "It is only within the situation grasped in its totality that the anatomical privilege forms a basis for a true human privilege. The truth of psychoanalysis could be found only in historical context." [Ce n'est qu'au sein de la situation saisie dans sa totalité que le privilège anatomique fonde un véritable privilège humain. La psychanalyse ne saurait trouver sa vérité que dans le contexte historique ( $D S$ 1:90-1).]

$D S$ 1:93.
} 
where a philosopher would stipulate "the good," but by pretending to be a scientist and not a philosopher he fails to argue for it properly, and an ethics which denies it is an ethics is particularly dangerous. ${ }^{33}$ Perhaps the deepest problem Beauvoir had with Freud was that in his system no human behavior can be fully authentic: anything we think, feel, or do is symbolic of, reducible to, something else, something sexual, something about myself that I don't have access to, although the analyst (supposedly) does. For her as for Sartre, Freud's account of unconscious motivation is unacceptable because it reduces purposive human activity, understanding, and choice, to the status of an illusion.

Sartre pursues this argument rather differently, and at great length, in Lêtre et le néant: his concept of "bad faith," and his insistence there on the individual's absolute freedom, required him to disavow the idea of an unconscious completely. I don't see Beauvoir as rejecting the idea of "bad faith"; in The Second Sex she tends to speak of a "fuite inauthentique" (inauthentic flight) rather than using the term "mauvaise foi," but the latter term does occur. Still, her story-examples tend to be more concrete than Sartre's, and more embedded in a social context. He sometimes sees "bad faith" when an individual attributes something to the social category he belongs to; Beauvoir sees refusing to admit that one belongs to a situated social category as a sign of bad faith. For instance, she writes in the introduction, "[c]learly, no woman can without bad faith claim to situate herself beyond her sex" - a sentence Parshley omitted entirely, as Moi points out. ${ }^{34}$

Beauvoir's skepticism can be illustrated quickly by an anecdote she takes from Denis de Rougemont: a woman goes into psychoanalysis because of a neurotic delusion that birds are attacking her; after a long, unsuccessful course of therapy the doctor happens to walk into the clinic garden with her and notices that birds really are attacking her ${ }^{35}$ Existentialism aside, the feminist relevance is clear. The same phenomenon-for instance, a deep and abiding anger-can look like a neurotic failure to "adjust to life," or a well-founded

33 She gives him failing marks in every philosophical field — epistemology, ethics, ontologyplus blames him, as others have blamed her, both for being a philosopher and for not being one.

"Il est clair qu'aucune femme ne peut prétendre sans mauvaise foi se situer par-delà son sexe" (DS 1:13). For Moi's analysis, see "While We Wait," 1012. Again it seems unnecessary to harp on this difference between Beauvoir and Sartre, especially since Sartre's position evolved during the war toward the view that a refusal of solidarity was a moral weakness, and toward a more realistic understanding of freedom as socially and historically conditioned.

DS 2:197. 
resistance to oppression, depending on whether one is inside, or outside, the clinical regime. ${ }^{36}$

Beauvoir suggests early in volume 1 that Stekel has somehow escaped the deep ontological error of reducing all human choice and all human behavior to unconscious sexual determinants. So one good explanation for Stekel's strong presence in The Second Sex is indeed the reason Beauvoir gives in La force de l'âge: he enables her to provide copious descriptive psychoanalytic accounts, without being tied to a Freudian ontology or "ersatz ethics." (A "nuisance to psychoanalysis" was precisely what she needed.) And he makes it possible to carry over the psychoanalytic claim that sexuality is fundamental to subjectivity, without making women the helpless victims of their drives. But then she dismisses him in a phrase, calling his analyses "superficial," as indeed they are.

Without entirely throwing out the contributions of psychoanalysis, some of whose insights are fruitful, we will therefore reject its method. First, we will not limit ourselves by taking sexuality as a given. That attitude falls short, as is shown by its impoverished description of feminine libido, which, as I've already said, psychoanalysts have never studied directly [de front], but only by starting from male libido. They seem not to know that the attraction men hold for women is fundamentally ambivalent. Freudians and Adlerians explain the anxiety the woman feels when confronted with the male sex organ as the inversion of a frustrated desire. Stekel saw better that it is a primary reaction [une réaction originale], but he accounts for it superficially — on his account, the woman is afraid of losing her virginity, of being penetrated, of pregnancy, of pain, and that fear acts as a brake on her desire. This explanation is too rational. ${ }^{37}$

$36 \quad$ On this point, see also Simons: “In describing a subject's failure to effect a transference or a sublimation (and surely the most obvious example here is in the 'failure' of a woman to become a heterosexual), a psychoanalyst, Beauvoir argues, 'does not suppose that they perhaps refused it and that perhaps they had good reasons for doing so; [the analyst] does not want to consider that their conduct could have been motivated by ends freely posed"” ("The Second Sex and the Roots of Radical Feminism," 156, quoting DS 1:92).

"Sans rejeter en bloc les apports de la psychanalyse dont certains aperçus sont féconds, nous refuserons donc sa méthode. D'abord nous ne nous bornerons pas à prendre la sexualité comme une donnée: que cette attitude soit courte, c'est ce que manifeste la pauvreté des descriptions touchant la libido féminine; j'ai dit déjà que jamais les psychanalystes ne l'ont étudiée de front, mais seulement à partir de la libido mâle; ils semblent ignorer la fondamentale ambivalence de l'attraction qu'exerce sur la femme le mâle. Freudiens et adlériens expliquent l'angoisse éprouvée par la femme devant le sexe masculin comme l'inversion d'un désir frustré. Stekel a mieux vu qu'il y a là une réaction originale; mais il en rend compte d'une manière superficielle: la femme aurait peur de la défloration, de la 
For Beauvoir, female sexuality is not a pale version of male libido- this is one of many moments in The Second Sex where Beauvoir indicates that women are different from men in ways that deeply matter-nor is woman's desire a mask or a symbol for something else. It needs to be studied, not for what it resembles, and not for what it conceals, but de front, head-on, as itself, for what it does. In other words, women's desire needs to be seen as authentic, just as the desire of a young girl to climb a tree results, not from penis envy, but from a desire to climb a tree. ${ }^{38}$ (Later Beauvoir will say that when a woman takes a lover, it is a lover that she wants. $)^{39}$

Whether she is right, in what follows, to describe that "primary" reaction as "this sort of appeal, at the same time insistent and terrified, which is female desire ... characterized by an indissoluble synthesis of attraction and repulsion," we may want to debate; and it is hard to know exactly what she means when she explains that

[t]he idea of "passive libido" is disconcerting because "libido" has been defined, based on the male, as pulsion, energy; but no one could conceive of light being at the same time yellow and blue; what is needed is the intuition of green. ${ }^{40}$

But it is clear that no one (woman or man) can claim without bad faith that Beauvoir did not see, or did not value, woman's "sexual difference." What is unusual is that she located this difference in the experience of sexual desire, rather than where traditionalists, and some feminisms, would place it, in the experience of sexual reproduction, which is to say, maternity (or "the maternal"). It is also worth noticing that, here as throughout, her discussion of women's embodied experience is not limited to sexuality: she continues,

[w]e would get closer to reality if instead of defining libido in vague terms like "energy," we brought the meaning of sexuality together with

pénétration, de la grossesse, de la douleur, et cette peur freinerait son désir; cette explication est trop rationnelle" ( $D S$ 1:92).

$38 \quad D S$ 1:94.

39 "[Q]uand elle prend un amant, c'est bien un amant qu'elle veut" (DS 2:422).

40 "Au lieu d'admettre que le désir se déguise en angoisse ou est combattu par la crainte, il faudrait considérer comme une donnée originale cette sorte d'appel à la fois urgent et effrayé qu'est le désir femelle; c'est la synthèse indissoluble de l'attraction et de la répulsion qui le caractérise.... L'idée d'une 'libido passive' déconcerte parce qu'on a défini la libido à partir du mâle comme pulsion, énergie; mais on ne concevrait pas non plus qu'une lumière puisse être à la fois jaune et bleue; il faut avoir l'intuition du vert" (DS 1:92-3). 
the meaning of other human attitudes: taking, capturing, eating, doing, dominating, etc., for it is one of the singular modes of taking hold of an object; the qualities of the erotic object should also be studied as it presents itself not just in the sexual act but in perception generally. Such a study would look outside the frame of psychoanalysis, which posits eroticism as irreducible. ${ }^{41}$

The contributions (apports) of psychoanalysis, in other words, are useful here only when subordinated to the contributions of phenomenology. Throughout her account of female development, Beauvoir will emphasize that there is more to the sexed (or gendered) body than the sexual body, for instance in the different ways girls learn to occupy physical space, the way aggressive or simply athletic activity is shamed out of us, and the psychological damage this does. ${ }^{42}$ But my point for now is simply that she has steered nimbly between two sorts of reductionism: Stekel seemingly can only see either attraction or repulsion, one at a time. Many if not most women will be able to falsify that claim by, um, consulting their own subjective experience. But the view attributed to Freud, which would reduce fear, repulsion, rejection of male advances to secret, repressed desire, is more obviously objectionable, since it smugly authorizes taking a woman's No as a sign that she really means Yes!—-something Freud himself did, when he insisted to his patient Dora that Herr K., who was harassing her (with her father's tacit complicity), was a perfectly attractive man and not all that old, really ... and sent her home. ${ }^{43}$

It is in volume 2, though, that Stekel comes into his own and prances about displaying his "cases" like a circus ringmaster, or like Charcot presenting his collection of femmes hystériques in the theatre of St. Anne's hospital. ${ }^{44}$ Here

41 'On cernerait davantage la réalité si au lieu de définir la libido en termes vagues d' 'énergie' on confrontait la signification de la sexualité avec celle d'autres attitudes humaines: prendre, capter, manger, faire, subir, etc.; car elle est un des modes singuliers d'appréhender un objet; il faudrait étudier aussi les qualités de l'objet érotique tel qu'il se donne non seulement dans l'acte sexuel mais dans la perception en général. Cet examen sort du cadre de la psychanalyse qui pose l'érotisme comme irréductible" ( $D S$ 1:93).

42 This crucial insight would be carried forward by such feminist phenomenologists as Sandra Bartky and Iris Marion Young.

43 See Charles Bernheimer and Claire Kahane, eds., In Dora's Case: Freud-HysteriaFeminism.

44 The engraving Freud, who had been Charcot's student, kept in his Vienna consulting room shows a half-clothed, contorted woman fainting on the arm of the doctor's whitecoated assistant, while the great man himself discourses to the audience. (US readers may recognize it from the cover of Bernheimer and Kahane's casebook to Dora.) Apparently a version of this spectacle, specifically designed for the edification of philosophy students, 
are a group of miserable maladjusted adolescent girls, many of them driven to suicide or psychosis by the onset of menstruation, by belief their breasts are too big, their blushes too red, their feet too ugly, their vaginas too small or in the wrong place or missing altogether. Here are some children fascinated by urination. Here are a horrifying series of wedding night vignettes, all piled up in a heap, repeating the same theme over and over, just as the woman (supposedly) repeats it obsessively every time she tries to have sex. Here are some deluded women who make themselves and everyone around them miserable by insisting they do not want what according to him they do want; in fact here (step right up!) is the "prevaricating woman" who only thinks she is frigid, the source for Sartre's claim in L'être et le néant that the woman he uses as an example of "bad faith" showed "objective signs of pleasure" though she denied feeling any ${ }^{45}$ As Le Dœuff shows, this assertion fails to conceive of female subjectivity at all, as the only subjectivity in Sartre's scene is male. (Having lost her unconscious, the "frigid woman" can now be blamed: Caprio's oxymoron, "the frigid nymphomaniac," and his rebranding of frigidity as "sexual inadequacy," 46 also takes off from this very point.)

Moreover, Stekel is linked with some of the parts of The Second Sex later feminists have found troubling: places where the female body seems irretrievably ugly; places where women seem not to know what they are feeling or where Beauvoir seems not to allow them the right to what they feel; places which seem to define women's experience of sex according to a paradigm we might question: for example, Beauvoir's statement that women's subordination is expressed through her position in sexual intercourse, which has troubled Toril Moi among others, can be linked to Stekel's Frigidity in Woman. ${ }^{47} \mathrm{He}$ appears very strangely in the rather odd chapter on "La lesbienne" (see chapter 2 below). His name is often close to something uncomfortable, to a place where the reader starts to worry that Beauvoir has lost sight of her project to tear down and de-essentialize a patriarchal myth about women and is either letting the myth speak through her or, worse, building a new myth of her own.

Furthermore, she uses his name in the way one invokes an authority, as evidence to support her own points; in some sections, the thickness and length of her quotations almost cede him the floor. The chapter on "Enfance" (Childhood)

was still going on in Foucault's day as it was in Beauvoir's (see Didier Eribon, Michel Foucault, 41-3, 50). For all I know it goes on there still.

Stekel, Frigidity in Woman, 2:62-3; Sartre, Lêtre et le néant, 93-7, Being and Nothingness, 95-9; Le Dœuff, Hipparchia's Choice, 64-70. See also Moi, "Freedom and Flirtation," where this "scene" from Lêtre et le néant is compared with similar episodes in L'invitée.

46 Caprio, The Sexually Adequate Female, 15.

47 Stekel, Frigidity in Woman, 2:3. See Moi, Making of an Intellectual Woman, 167-68. 
closes with a quotation of almost two pages: Beauvoir calls this a "detailed confession" which "constitutes a concrete synthesis of all the moments we have studied separately" 48 And finally, the concept of frigidity sometimes gets away from its owner and walks around on its own. Sometimes this leads to a sensible analysis, sometimes to a silly side-comment, as when she says that Scandinavian or Dutch women tend to be "clean and cold." ${ }^{49}$ While Stekel's name has dropped out by the final section, "Vers la libération" (Toward Liberation), frigidity figures importantly in the account of sexuality given there. ${ }^{50}$

Politically speaking, Stekel is hard to pigeonhole. His homophobia is profound; but he crusaded for a recognition of masturbation and childhood sexuality as normal and healthy. His conclusion decries the sexual double standard and the reduction of women to only a "sexual creature," ${ }^{11}$ but also rants against "defeminization": "maternal love has always been regarded as something lofty, sacred, and unimpeachable" and "the woman who withholds from her calling as mother ... denies her womanhood."52 It is equally hard to say simply whether his influence on Beauvoir was progressive or the reverse. For instance, in her chapter on motherhood, she quotes his ringing denunciation of the hypocrisy of laws forbidding abortion: "the prohibition of abortion is an immoral law because it is bound to be violated every hour of every day."53 But a moment later, his name authorizes the idea that morning sickness and even miscarriage can result from a woman's internal refusal of motherhood and femininity and from her hostility toward the fetus - an idea that has rightly troubled feminists (and is, medically speaking, nonsense). In fact both his helpfulness and his faults have the same root: because he rightly refuses to naturalize (and normalize) human behavior with some sort of Freudian determinism, he sometimes risks falling into a purely voluntaristic conception of human feeling, which means that people who are unhappy or oppressed can be blamed. (Both Sartre and Beauvoir have been charged with a similar voluntarism.)

But many other points in The Second Sex show that Beauvoir should have been able to see through him. Her denunciation of psychoanalysis as an "ersatz

48 " [U]ne confession détaillée. Elle constitue une synthèse concrète de tous les moments que nous avons étudiés séparément" ( $D S$ 2:85).

$49 \quad D S 2: 156,271$.

50 DS 2:611-13, 657-59.

51 Stekel, Frigidity in Woman, 2:274-75.

52 Ibid., 2:292 and 2:300. See Cryle and Moore, Frigidity, 216-21 for an excellent, and contextual, discussion of Stekel's conclusion.

53 " $[\mathrm{L}]$ a défense de l'avortement est une loi immorale puisqu'elle doit être obligatoirement violée, tous les jours, à toutes les heures" ( $D S$ 2:343). 
ethics" certainly applies to Stekel, who at best is a kind of ersatz Freud. That she did, in fact, see through him becomes clearer if we turn from her work to his.

\section{$4 \quad$ Stekel par lui-même}

Opening Frigidity in Woman, we find that Stekel has his own system, his own theory of human sexual life, about which Beauvoir never says a word. He begins by deploring a sad fact about the modern world, an "unhealthy age": because of evolution, and "the influences brought about by refinement in culture," frigidity and impotence are on the rise; they are thus most prevalent in educated people of the upper classes. This is because, he says, human beings have a "double-chamber arrangement" of the nervous system, and "the specific character of every love is determined by the struggle between brain and spinal cord," between the animal and the spiritual side of Man. ${ }^{54}$ "Primitive folk" mostly don't have these problems because they are closer to unproblematic animality. ${ }^{55}$ (I'm not making this up.) Since love is immortal and divine, as the poets tell us, it is tragic that so many people (and so many of the best people!) are now incapable of it. "What they need is a new prophet who shall point their way to a new track and set them on the path which leads into the kingdom of happiness and love." ${ }^{56}$ This prophet, obviously, he plans to be.

But before he can get to sexual dysfunctionality, he wants us to know what love is. He begins to explain his theory that everyone has an "individual love requisite" by analyzing the phenomenon of love at first sight. ${ }^{57}$ All love is at root love of self, and the lover recognizes himself in the other person: we can see this, for example, in the fact that foot fetishists take exquisite care of their own feet, and that a man who likes to have his ear kissed will kiss his partner's ear. Also (?) all love comes from infantile fixations. So, a certain man can only be aroused by a woman who is missing a tooth; this can be explained by the fact that his childhood nurse was missing the same tooth. Another man marries a woman because, he later realizes, she has the same "sideward glance" as his mother. Also (?) the "law of bipolarity" may bring about a reversal. ${ }^{58}$ Bald men desire women with lots of hair. Blondes are favored because mankind is in flight from sexuality. Women with dark hair are preferred because dark hair is

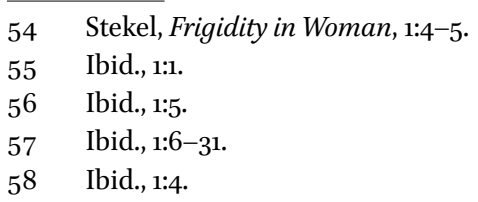


"more sensuous." ${ }^{99}$ Now, anyone accustomed to reading psychoanalytic material will not be surprised that conflicting examples generate explanations that seem contradictory; indeed, unconscious motivation and overdetermination explain why this must be so. But while Stekel mentions both those ideas, he does not really take them on board, and every one of his conflicting explanations is presented as if it were a universally applicable maxim.

As the discussion continues, curious anecdotes proliferate, innocent of theory. Did you know that Descartes could only be attracted by cross-eyed women? Henry III of France "is said to have had recourse to the odor of excreta as a means of refreshing himself from the fatigue of dancing" and once fell in love with a woman after wiping herself with her sweaty chemise. ${ }^{60}$ Smell is very important to some people; another man cares deeply about the shape of the ear (and wishes to have intercourse with it). We meet the man who could bring on orgasm by fondling a wart ... the man who sucked the dental plates of prostitutes and could orgasm in no other way ... and then (right there!) is an example Beauvoir uses, of a woman who fell in love from a distance with a famous tenor, but did not wish to meet him in the flesh. ${ }^{61}$

What's going on here?

It's certainly more readable than Freud, because where Freud hedges everything around with scientific apparatus and methodological reflection, Stekel simply asserts, as the expert, that he knows. Such theory as he has lies close to the surface. The "law of bipolarity" is explained as follows: "The self consists of opposite strivings which act as counterparts. One's choice may follow the principle of identification or the opposite principle of differentiation." ${ }^{2}$ This "law" forms the basis of his claim to have invented the concept of "ambivalence," which he accused Freud of stealing, but does it amount to anything more than two clichés, "birds of a feather" and "opposites attract," laid end to end? The literalness of his analysis borders on parody.

Women who "have fallen" or who struggle against temptations, throw themselves out of the window and into the street; ${ }^{63}$ the man who entertains secret thoughts of poisoning somebody, takes poison; one who

\footnotetext{
59 Ibid., 1:14.

6o Ibid., 1:17.

$61 \quad$ Ibid., 1:52-3; DS 2:419.

62 Ibid., 1:11.

63 This example seems also to have been picked up by Sartre, but by way of Pierre Janet: see The Transcendence of the Ego, 100.
} 
yearns after the flames of love sets fire to himself; he who believes himself surrounded by poisonous thoughts, turns on the gas. ${ }^{64}$

He believes in the seven-year itch (illustrated with examples from the life of Goethe), and in Fliess's notorious theory that the nose plays an important role in sexual life: for example, he knows a student who could have an orgasm simply by kissing a woman on the nose. "The size of the nasal openings also plays a larger role in sexual excitation than is usually recognized."65

Children's incestuous feelings for parents are on the rise because upperclass parents, having fewer children, spoil them through "overtenderness" ("the only child is almost always fated to be a neurotic," and favorite children are more likely to break down);66 this may be leading to class suicide, a disaster he parallels to the devastation of the First World War. He also says, though, that "love disorders" are "a kind of automatism which intervenes to prevent overpopulation." 67 On the other hand, the prevalence of erotic fixations upon servants and the lower classes is due to neglectful parents who abandon their small children to the care of wet-nurses. ${ }^{68} \mathrm{He}$ finds all these situations problematic, seemingly without noticing when his claims logically cancel one another out.

So did Stekel, as Beauvoir and Sartre believed, propose a psychoanalysis without the unconscious? Yes, if by "unconscious" one means, "deep." In fact he uses the terms "unconscious" (and also "preconsciousness" and "coconsciousness") from time to time, but unsystematically. Frigidity he seems to think is more or less conscious: you "can get the woman to admit" that she is angry, or thinking about her father or about God; one woman who had "presented" with a wish to be cured finally "admitted" that she had been telling herself funny stories as a distraction, to prevent herself from rewarding her husband with her orgasm. Has this woman gained some healing insight into her own unconscious motivation, or has she merely been caught lying? (That Freud, too, uses phrases like "I brought her to admit," in Dora for example, doesn't make this any easier to pin down.)

Some of this is funny, but it can't be dismissed as harmless. The smug, moralizing account of the upward aspiration and the downward longing, and his worries about the sexual degeneracy of modern Europe are disturbingly close

\footnotetext{
64 Stekel, Frigidity in Woman, 1:41.

65 Ibid., 1:16.

66 Ibid., 1:36.

67 Ibid., 1:70.

68 Ibid., 1:37, 39 .
} 
to such fascist and protofascist writers as Otto Weininger and Max Nordau, a discourse whose results we know (though he could not). ${ }^{69} \mathrm{He}$ also leaves one with the feeling that women's accounts of their own experience are not to be trusted - though men don't come out looking very good, either. The solutions he proposes to the dilemmas arising from "individual sex requirements" can feel a little scary. One man is worried because he is sexually aroused only by very young girls - he has opened a candy store in order to be able to see them all the time, but he is afraid he will one day act on his desires and end up in jail. Stekel convinces him to marry a very small woman (located through a marriage broker), and to dress her up in pigtails and school uniform: they live happily ever after. ${ }^{70}$ In explaining how what looks like frigidity may actually be concealed masochism (a theme Beauvoir will take up), he tells us about a woman who drove her husband so crazy with her complaining that finally he beat her, which turned out to be what she really wanted-and they too lived happily ever after! ${ }^{71}$ At this point Stekel quotes Nietzsche, seemingly with approval: "when you go to a woman, forget not your whip!" Not nice, no.

And yet, irritatingly, every once in a while he gets things totally right. There's nothing wrong with masturbation, he says: this was one of his explicit disagreements with Freud. "Perhaps there is no such thing as a normal person."72 Men have problems too. "Disorders of our love life are truly social diseases."73 "The well-known saying, the criminal is the crime of the state can be paralleled by 'the neurotic is the crime of the family."'74 Total frigidity does not exist, all women are able to have orgasms; adult traumas matter, and one should not waste time looking for childhood "keys" when an actual cause, like a rape, or a husband who does not know what he is doing, is staring one in the face. Plus, he seems to see libido as gender-neutral: there seems to be (for him) both a will to dominate, and a will to be dominated, in sex, but neither gender has a monopoly on either position; and he takes it for granted that women have (all

69 See Erin Carlston, Thinking Fascism: Sapphic Modernism and Fascist Modernity, for a good summary of this discourse and its widespread influence on otherwise sensible people of good will. Some of the incoherence of Stekel's conclusion may be attributed to his belated understanding of the consequences of Hitler's pro-natalism, and to the war that would make him, like Freud, a refugee. But on page 291 of the English translation he is still saying that "the future of Europe looms austere and dark... It is becoming already obvious that the fertility of the Slavic race will destroy Germanic organization and culture after it shall appropriate it to its own uses."

70 Stekel, Frigidity in Woman, 1:24.

71 Ibid., 1:69.

72 Ibid., 1:28.

73 Ibid., 1:33.

74 Stekel, Autobiography, 44. 
sorts of) sexual desires which they, like men, will attempt to satisfy in some way.

But as I said above, the progressive and the retrograde have the same roots. His refusal to categorize sexual behavior as deviant ("there is no such thing as a normal person") leaves him no room to condemn rape or pedophilia: he notes several times an assault by a brother, a grandfather, with no particular affect, although (unlike Freud) he is not provoked to doubt the woman's statement that the abuse really happened. The shallow roots of sexual proclivities mean frigidity is not essentialized, can be caused by a bad husband, helped by better "technique"; it also means that lesbianism is "curable," and enables him to terminate many of his triumphant cases, not with clarifying insight (in which he seems largely uninterested) but with a simple "heterosexual adjustment," and wedding bells. The doctor-hero brings closure and respectability to the flood of narrative, supposedly neutralizing (and thereby authorizing) its pornographic potential. "Amor Vincit Omnia" is his conclusion: one patient (identified as a "backfisch," a young girl) says to him, "you may well be proud of what you have done for me." ${ }^{\prime 7}$ How this can be reconciled with the seemingly fixed nature of the "individual love requisites" is unclear.

But perhaps it's a mistake to take the theory seriously. Stekel's strong point (and his legacy to the drugstore paperback) is as a raconteur of spicy stories. It doesn't advance his analysis, or the cause of science more broadly, for us to learn that case 34 (a lesbian) "can whistle remarkably well and she drinks on average daily about ten glasses of beer,"76 but it certainly brings her to life for us. His second volume largely abandons (pretention to) theory in favor of serial narrative: "Confessions," "Psychoanalysis of a Case of Dyspareunia," "The Analysis of a Messalina," "Fragmentary Analysis of a Transvestite." It does seem possible he made some of these up, if I judge by an admittedly novel-ridden conception of verisimilitude. (Some of them I hope he made up.) And maybe Beauvoir didn't actually care whether he made them up? At one point she refers to a case study subject as a "heroine."77

So, if everything is shallower and less tragic than Freud thought, and most of it can be changed, is this good? On the one hand, the truly frigid woman has been de-biologized and de-pathologized; on the other hand, a new monster has been created, the "prevaricating woman," who pretends, or claims, to be frigid, as part of a battle of the sexes she is carrying out in her own family. In The Second Sex, too, we hear about women who are crispées (clenched), about

\footnotetext{
75 Stekel, Frigidity in Woman, 1:208.

76 Ibid., 1:121.

77 DS 2:70.
} 
women's sexual expression of their rancune (resentment, rancor, desire to take revenge). Now, Beauvoir was very lucid in the first volume about how selfserving men's accounts of women's sexual experience could be. In her introduction she describes Marynia Farnham's Modern Woman: A Lost Sex, whose jeremiad about modernity is much the same as Stekel's, as "fort agaçant" (very annoying), ${ }^{78}$ in later chapters she saw through D.H. Lawrence, Montherlant, Claudel ... Couldn't she see through this risible charlatan?

\section{$5 \quad$ What She Made of What He Made of Us}

I think she did see through him. Putting the texts side by side, it's striking that she almost always (though not quite always) quotes only his example, omitting his reductive analysis of it. Racquelle Bostow has noticed that "Beauvoir uses only the adjective 'frigid' (frigide) and never the substantive 'frigidity' (frigidité), which suggests a fixed sickness" or a personality "type."79 The breezy arrogance of the healer-interpreter that resounds through Stekel's own writings is never heard in The Second Sex, either as his triumph or as hers. It is as if she values Stekel's documentary evidence of women's problems, but find his solutions too derisory even to combat; she removes them as neatly as if she'd been reading with a pair of scissors in her hand. It's true that Stekel's name appears uncritically, as though he were a simple professional authority cited to back up her view. But considering how much The Second Sex relies on psychoanalytic and sexological descriptive accounts, it is striking that a truly therapeutic discourse is remarkably absent: no one is cured.

Something similar happens with Helene Deutsch. As Éliane LecarmeTabone has noted in a detailed and convincing inquiry, Beauvoir cites Deutsch's work very frequently in The Second Sex, while continuing to directly oppose Deutsch's naturalistic and normative assumptions about a specifically "different" feminine sexuality. ${ }^{80}$ Beauvoir demolishes Deutsch's theory of female masochism in a few well-chosen words, but continues to use her examples copiously, and feminists ever since have wondered why Beauvoir spends so much

$78 \quad D S$ 1:12. For discussion of Farnham, see Jane Gerhard's excellent article "Revisiting 'The Myth of the Vaginal Orgasm,"' 458-59.

79 Bostow, "Frigidity According to Beauvoir," 4.

8o Éliane Lecarme-Tabone, "Beauvoir et Hélène Deutsch," 47-61. Stekel and Deutsch are the two most salient authorities dealt with in this way, but there are others: the overlapping fields of psychoanalysis and sexology are very well represented. Beauvoir's use of discredited, or at least unfashionable, sources, and the issue of "guilt by association," will be considered more broadly in later chapters. 
time discussing women's masochism, if she did not after all see female sexuality as intrinsically masochistic and, well, bad.

But perhaps we can see why Stekel and some of the other authorities that now seem problematic represented such an important resource for Beauvoir that she used them, in spite of flaws she saw, if we reflect on what her alternatives were, since most of what we'd now turn to ("standard works" or more popular materials) had yet to be written. Even Kinsey's volume on women did not appear until $1953 .{ }^{81}$ Beauvoir's own sexual education had been so rudimentary, she tells us in her memoirs, that as a child she got a meaningful piece of information from a scrap of newspaper hanging in the bathroom (to be used as toilet paper). ${ }^{82}$ As a phenomenologist, if not quite yet as a feminist, she was not satisfied to make up her examples: she needed real subjective accounts, and these were few and far between. So perhaps she read Stekel as lesbians in the 1950s would read pulp fiction (and indeed pulp psychoanalysis!): simply searching for representation, which was very hard to find. In an economy of representative scarcity, biases can be ignored or silently corrected, even when they do not pass unnoticed. One takes what one needs and leaves the rest.

Beauvoir tells us that The Second Sex grew out of an autobiographical impulse. But - and this seems important—it did not stop there. Indeed, when (according to this account) Sartre convinced her that an important part of being Simone was being female, and she realized that she had not realized this, she went in search of information, information which would precisely not be drawn from her own subjective experience, which supposedly had failed to teach her anything useful about it. (Perhaps this is why her method, especially in the second volume, is to pile example on example, to the point where one can almost forgive Parshley for saying, OK, we get it, enough already.) She tells us she went to the Bibliothèque nationale, ${ }^{83}$ where she read everything on the

81 See Coffin, "Beauvoir, Kinsey, and Mid-Century Sex": "[Beauvoir] was reading Kinsey's report on men in December 1948, as she composed the introduction to The Second Sex and began to write volume 2. 'There are some very interesting things in it,' she wrote to Nelson Algren, 'and other rather funny ones! I should be pleased if the same work was already done for women; it would help me for my book.' That reading may have helped her open The Second Sex with the dismissal of the 'voluminous nonsense uttered about women in the last century' - a gesture of grand revisionism that parallels Kinsey's" (27).

82 Mémoires d'une jeune fille rangée [hereinafter $M J F R$ ], 139-40. See also 28, 56, 77-8, 80-2, $113^{-21}, 138-41,151-55,224-28$. One of Beauvoir's targets in that book, as in Quand prime le spirituel and The Second Sex, is the inadequacy of sexual education. Whether this situation has really improved, either for scholars or for curious little girls, is not a question I can take up here.

83 La force des choses (hereinafter FCh) 1:136, 235, 258-59; Force of Circumstance, trans. Richard Howard (hereinafter FCirc), 103, 177-78, 195-96. See also "The Art of Fiction No. 35," interview with Madeleine Gobeil. 
subject of women that had appeared in English or French and used the methods she had learned in her "formation universitaire" to distinguish the material that "really counted" from myths and prejudiced accounts. ${ }^{84}$ How close we are here to Virginia Woolf who, given the assignment to lecture on women and literature that would become A Room of One's Own, duly trotted off to the British Library with her notebook and looked under W. On the other hand, how far we are, really, from Woolf's surprise and horror at what she found, and her decision to seek the truth about women elsewhere, around the streets of London and in her own common sense. Uncovering her own anger, unmasking the anger of the patriarchs, Woolf "unhooked" herself from Professor X with his measuring rod and from the scruffy, grunting student sitting next to her, and also from the whole prestige of scholarly inquiry, precisely the prestige Beauvoir invokes in reminding us (perhaps defensively) of her own scholarly accomplishments. Where Woolf in the library threw up her hands, went for a walk, and started from scratch, Beauvoir simply got out another pack of blank notecards (as it were).

So it is clear that scholarly inquiry, particularly empirical inquiry, and even more particularly inquiry with some basis in the physical sciences, maintain a prestige and a value for her. Despite her critique of knowledge-formation, her unmasking of myths and the self-interested motivations behind them, she remains at Sandra Harding's first stage, where the methods and the ethical standards of science are invoked to judge those who fail to meet their own standards and procedures ("sexist science is bad science"). ${ }^{85}$ But this does not preclude placing an equally high epistemological value upon accounts drawn from everyday experience, introduced by a phrase such as "I knew a young woman who" (j'ai connu une jeune femme qui), "a woman told me" (une femme m'a dit), or or "I remember a friend of my youth, who" (je me rappelle une amie de jeunesse à qui). There is also a proliferation of accounts drawn

84 We may well feel that her university education had taught her nothing of the kind, marked as it must have been by biases and lacunae. But she may mean simply that she had learned to work quickly through a great deal of material, and not to believe everything she read. It's worth remembering that at that time "psychology" was studied as a branch of philosophy, and would have included much that we would now have trouble recognizing as "science."

85 Sandra Harding, The Science Question in Feminism. Only in a later stage does "standpoint theory" come to see the procedures as problematic in themselves (exclusionary, and so forth). One may regret this commitment of Beauvoir's, especially when trying to teach the biology chapter! But she herself never regretted it, and employed much the same technique, and the same intellectual structure, in writing La vieillesse two decades later. Indeed any expectation of such regret would be anachronistic. 
from women's memoirs and letters, and from fictional texts, some written by women and some by men. I was surprised to realize, in the course of my beancounting, that the most frequently cited name in The Second Sex is Colette's. Sophie Tolstoy also scores high. Beauvoir is even willing to use a passage from a novel by Mauriac, a writer she particularly disliked (and who returned the favor), because the heroine seemed to be describing women's sexual misery in a particularly cogent way. She calls upon women's accounts of their own experience even when these accounts are tremendously mediated. And while different kinds of sources might, one would think, imply different kinds of "truth claims" or levels of authority, Beauvoir does not subordinate one level of example to another: they are simply linked paratactically, side by side. So the sexology does not govern or explain the fiction or the personal anecdote; the heroine of the Mauriac novel, or the Dorothy Parker story, is no more and no less "made up" than the "heroine" of Stekel's case history. ${ }^{86}$

I suspect Karen Vintges is right to label this method phenomenological; ${ }^{87}$ if, as Sartre was excited to discover, Husserl's method makes it legitimate to "do philosophy" about a glass of beer, or an apricot cocktail, ${ }^{88}$ surely one can also then do philosophy about a menstrual pad. And I think she's also right to see “j'en connais des femmes qui" as one of Beauvoir's most profound legacies to the women's movement. To give one example: leafing through the old version of Our Bodies, Ourselves, I was struck by the stories, women giving accounts of their sexual histories. This written-down version of consciousness-raising triangulates on the "truth about women," sketches a community of seekers after truth by means of what Woolf scholars used to call "unity in multiplicity." The individual and the collective are not opposed but allied, at least on the page.

But there is one sort of example Simone de Beauvoir never uses in The Second Sex. She never uses a hypothetical. This is interesting well beyond the fact that it is another "swerve" from the Sartre of L'être et le néant ("Suppose I go into a café looking for my friend Pierre...," "Suppose a waiter asks me...," etc.) and a radical departure from a venerable, perfectly well-respected, philosophical manner of "writing the personal" - still going on wherever philosophers gather ("we tend to say...," "I can imagine ...")—a way of thinking and writing in which Beauvoir became completely uninterested. She was looking for data.

Still, to say she got something she needed from Stekel is not to excuse her, exactly. As she herself said (writing about the Marquis de Sade), "one is always

86 For discussion of what Beauvoir believed about the truth value of fiction, see Toril Moi, "What Can Literature Do? Simone de Beauvoir as Literary Theorist."

87 Karen Vintges, Philosophy as Passion: The Thinking of Simone de Beauvoir.

$88 F A, 157$. 
more influenced than one believes by the ideas against which one is fighting." ${ }^{89}$ I take it as axiomatic that feminism at any period will be inextricably entwined in other discourses of that time about women and sexuality. Cora Kaplan, writing about Mary Wollstonecraft, has made the observation that "all feminisms give some ideological hostage to femininities and are constructed through the gender sexuality of their day as well as standing in opposition to them," ${ }^{90}$ and Foucault says similarly that at any given point in history, the discourses of repression and liberation will be the same discourses. ${ }^{91}$ We may find this disconcerting, or we may find it empowering; the point for my purposes is to look not at what the discourse of frigidity was (tainted, "problematic"), but at what in this text it did, and does.

I'm now going to suggest some ways in which against all odds, and counterintuitively, examples from Stekel helped Beauvoir make arguments that are key to the usable feminism of The Second Sex. To summarize, I believe he helped her establish that women do have, and are entitled as human beings to have, a sexual subjectivity of their own; he furthered her account of women's character as constructed by their situation, thus potentially changeable; and he enabled her to provide a rich, detailed, concrete, complex picture of women's misery under patriarchy, fueling the argument for change.

First: His detailed examples of childhood sexual play help do away with the myth of childhood innocence. Kids are fascinated by urination, kids try to find out about sex and get some strange ideas, kids play doctor, kids masturbate, girls do this just as much as boys: get used to it. In fact, Beauvoir says, it's a "persecution" to try to stop them. ${ }^{92}$ She returns to this topic prominently in her book's conclusion, giving psychoanalysis credit where she feels it is deserved:

It is already progress that "depraved" little girls are no longer cauterized with a red-hot iron; psychoanalysis has made parents a bit better informed; but women's puberty and sexual initiation still come to pass under such deplorable conditions that none of the objections people make to the idea of a radical change are valid. ${ }^{93}$

89 “[O]n est toujours plus influencé qu'on ne croit par les idées qu'on combat" (Faut-il brûler Sade?, 6o).

$90 \quad$ Cora Kaplan, Sea Changes: Essays on Culture and Feminism, 49.

91 Michel Foucault, The History of Sexuality: Volume 1, an Introduction, 95-101.

$92 \quad$ DS 2:79.

93 'Qu'on ne cautérise plus au fer rouge les fillettes 'vicieuses,' c'est déjà un progrès; la psychanalyse a un peu instruit les parents; cependant les conditions actuelles dans lesquelles s'accomplissent la formation et l'initiation sexuelle de la femme sont si déplorables qu'aucune des objections que l'on oppose à l'idée d'un radical changement ne saurait être 
(Freud himself was much more conservative than Stekel about masturbation, including with his own children. ${ }^{94} \mathrm{~A}$ key section here is the long quotation, two and a half pages, from Stekel's case study of a "Viennese süße Mädel" with which Beauvoir concludes her chapter on "Enfance." This is the story which Beauvoir says "constitutes a concrete synthesis of all the moments we have studied separately"; it shows children indulging their curiosity about the body through inquiry and sex play of various kinds. Beauvoir comments:

Even though this is an ordinary [normal] and not a pathological case, people might call this child exceptionally "perverse." She was only less closely supervised than others. ${ }^{95}$

That it was "normale" for children to be interested in sex did not go without saying.

Second: Indeed, this did not go without saying even for adult women. On page 237, I began to overcome my distaste for the word "frigidity," because I began to historicize it. Beauvoir has been discussing the reluctance of medical and social authorities to give women access to drugs which will alleviate the pain of childbirth. Something analogous happens, she thinks, with sex itself:

$[\mathrm{M}]$ ales haven't scrupled to refuse their partner sexual happiness; it has even struck them as advantageous to deny her the temptations of desire by denying her the autonomy of pleasure. ${ }^{96}$

This is followed by a footnote.

valable" (DS 2:657). ("Formation" is hard to translate, since it can also mean "development" more generally. Parshley has "training," which is certainly right in a phrase like "formation universitaire," and here does preserve the sense that the girl is being formed, rather than forming herself: someone writing now might simply say, "socialization." But "formation" can also be applied to, for instance, a fruit, as it develops from a blossom, so both biology and culture are kept in play.)

94 Anna Freud's biographer and Paul Roazen have separately indicated the ill effects on Freud's own children of their father's Victorian intransigence on this point. See Roazen, Freud and His Followers, 15; Elizabeth Young-Bruehl, Anna Freud: A Biography.

95 "On dira peut-être—bien qu'il s'agisse d'un cas normal et non pathologique—que cette enfant était d'une exceptionnelle 'perversité'; elle était seulement moins surveillée que d'autres" ( $D S_{2: 88)}$.

96 "On comprend donc que les mâles n'aient eu aucunement scrupule à dénier à leur compagne le bonheur sexuel: il leur a même paru avantageux de lui refuser avec l'autonomie du plaisir les tentations du désir" ( $D S$ 2:237). 
Even today, woman's claim to pleasure makes men angry: an astonishing document bearing on this point is Dr. Grémillon's little booklet, The Truth About Woman's Venereal Orgasm. We learn from the preface that the author, a hero of the Great War who saved the lives of fifty-four German prisoners, is a man of the highest morality. Taking violent exception to Stekel's work on The Frigid Woman, he declares (among other things): "The normal woman, the good producer of children [pondeuse, a word usually applied to hens, refers literally to a good layer of eggs], has no venereal orgasm. Numerous are the mothers (and the best ones) who have never felt the fantasmatic spasm ... The erogenous zones, usually latent, are not natural but artificial. People boast of acquiring them, but they are the stigmata of abject failure.... You can tell this to the professional lady's man [homme de joie - this is an insulting neologism: a fille de joie is a prostitute] and he won't care in the least, he wants his partner in crime to have a venereal orgasm and she will have one. If it doesn't exist it will be brought to exist. The modern woman wants to be made to vibrate. We reply: Madam, we haven't got the time, and hygiene forbids it! ... The man who creates erogenous zones is working against his own interest: he creates insatiable creatures. The whore can drain innumerable husbands dry without tiring herself .... the woman with a 'zone' becomes a new woman with a new state of mind, sometimes a monstrous woman who can go as far as crime ... There would be no neurosis and no psychosis if people could be persuaded that 'making the beast with two backs' was as indifferent a matter as eating, urinating, defecating, sleeping ...."97

97 Parshley gives only: “Even in our time, women's claim to sexual pleasure still arouses male anger. In a small work on the female orgasm, a Dr. Grémillon, taking issue with Stekel, declares that the normal, fertile woman has no orgasm. He goes on to say that erotogenic zones are artificial, not natural, they are signs of degeneration; to create them is unhygienic and foolish, for women then become insatiable, new and terrible creatures, capable of crime, and so on" (436). What gets lost here is both what is most outrageous in the original statement and what is most outraged about Beauvoir's counterattack: the texture, the grain of the voice.

"De nos jours encore, la prétention de la femme au plaisir suscite de mâles colères: sur ce point un document étonnant, c'est l'opuscule du docteur Grémillon: La vérité sur l'orgasme vénérien de la femme. La préface nous apprend que l'auteur, héros de la guerre de 14-18, qui sauva la vie de cinquante-quatre prisonniers allemands, est un homme de la plus haute moralité. Prenant violemment à partie l'ouvrage de Stekel sur La femme frigide, il déclare entre autres: 'La femme normale, la bonne pondeuse n'a pas d'orgasme vénérien. Nombreuses sont les mères (et les meilleures) qui n’ont jamais éprouvé le spasme mirifique.... Les zones érogènes le plus souvent latentes ne sont pas naturelles mais artificielles. On s'enorgueillit de leur acquisition, mais ce sont des stigmates de dé- 
Repulsive as we find the concept of frigidity, what it replaced was in some ways worse: the good woman and mother as passionless, the woman who feels (or thinks she feels) sexual pleasure as a shameless prostitute, a devourer of men. Where Stekel blamed modernity for impairing sexual fulfillment, Grémillon blames modernity for creating it in the first place: the only excuse for sex in his view would appear to be reproduction. As social historians have shown, the "new woman" of the early twentieth century created a moral panic, implicitly linked to a nationalist moral ideology, and here we have a prime example. ${ }^{98}$

Perhaps it was progress, then, to regard "frigidity" as a problem rather than an accomplishment? Stekel's talk of "cures" is repellent, but if it's a problem that sexual feeling in women can be missing, it must be definition normally or naturally be there. Logically, one must first argue that women legitimately have sexual feeling before one can criticize the way men have attempted to channel and misdescribe it, whether along the lines Anne Koedt will develop, or in the ways Beauvoir will go on (at length) to do.

So, going back to the quotation from La force de l'âge, perhaps frigidity and passion are not opposites after all. There's a nascent politicization of female sexuality: it is part of being human, and thus each woman has a right to it, a right she'll need to fight for, because there are still those who would deny it to her.

Third: In the chapter on "La jeune fille" (The Young Girl), Beauvoir mobilizes many examples from Stekel to make her point that female adolescence is a "travail," a "work" in the sense that psychoanalysts speak of "the work of mourning."99 Sexuality must be learned, and the way most girls learn it is awful. He is one of many authorities here who provide precise, detailed information, which Beauvoir folds together into a collective phenomenological account. For instance:

chéance.... Dites tout cela à l'Homme de joie, il n'en tiendra pas compte. Il veut que sa camarade de turpitude ait un orgasme vénérien et elle l'aura. S'il n'existe pas, on le fera naître. La femme moderne veut qu'on la fasse vibrer. Nous lui répondons: Madame, nous n'avons pas le temps et cela nous est interdit par l'hygiène!... Le créateur des zones érogènes travaille contre lui-même: il crée des insatiables. La gouge peut sans fatigue épuiser d'innombrables maris ... la 'zonée' devient une femme nouvelle avec un état d'esprit nouveau, quelquefois une femme terrible et pouvant aller jusqu'au crime.... Il n'y aurait pas de névrose, pas de psychose si on était persuadé que 'faire la bête à deux dos' est un acte aussi indifférent que manger, uriner, déféquer, dormir..." (DS 2:237, ellipses and emphasis in original).

98 See Cryle and Moore, Frigidity, 243-47; Mary Louise Roberts, Civilization Without Sexes: Reconstructing Gender in Postwar France, 1917-1927; Christine Bard, Les garçonnes: modes et fantasmes des années folles.

$D S$ 2:140. 
According to a survey reported by Havelock Ellis in 1896 , out of one hundred and twenty-five students in an American high school, thirty-six at the moment of their first period knew absolutely nothing about the matter. Thirty-nine had some vague acquaintance with the idea. That is to say, more than half of them were in ignorance. According to Hélène Deutsch, things had hardly changed in 1946. Ellis cites the case of a young girl who threw herself in the Seine at Saint-Ouen because she believed she had contracted an "unknown disease." In "Letters to a Mother," Stekel also tells the story of a child who attempted suicide, seeing her menstrual flow as a sign and a punishment for the impurities that soiled her soul. It is natural that the girl would be frightened: it seemed to her that her life was slipping away... ${ }^{100}$

Whatever one may think of any of these authorities as theorists, what Beauvoir is doing is mining them for examples, for data if you will, to support her own claim that girlhood is hell. This is entirely a cultural and social account, and the quotations, often long, are in the first person, as in the following example (Beauvoir footnotes Frigidity in Woman), which begins "une femme confie" (a woman confides):

I suffered from a feeling of physical inferiority, maintained by constant criticisms at home. My mother in her exaggerated vanity always wanted to show me off to advantage, and she always had a long list of pointers for the dressmaker, to conceal my defects: the sloping shoulders, the tooprominent hips, the too-flat backside, the overfull breasts, etc.... I tortured myself particularly about my feet which during puberty were very ugly and people gave me a hard time about the way I walked .... There was certainly some truth in all this, but they made me so unhappy .... I was sometimes so intimidated that I no longer knew at all how to stand.

100 "D’après une enquête rapportée en 1896 par Havelock Ellis, sur 125 élèves d'une 'high school' américaine, 36 au moment de leurs premières règles ne savent absolument rien sur la question, 39 avaient de vagues connaissances; c'est-à-dire que plus que la moitié d'entre elles était dans l'ignorance. Selon Helen [sic] Deutsch, les choses en 1946 n'auraient guère changé. H. Ellis cite le cas d'une jeune fille qui s'est jetée dans la Seine à Saint-Ouen parce qu'elle se croyait atteinte d'une 'maladie inconnue.' Stekel, dans les 'lettres à une mère,' raconte aussi l'histoire d'une enfant qui tenta de se suicider, voyant dans le flux menstruel le signe et la punition des impuretés qui souillaient son âme. Il est naturel que la jeune fille ait peur: il lui semble que c'est sa vie qui lui échappe" (DS 2:68-9). 
If I met someone my first thought was always, "if only I could hide my feet."101

Is there anything outdated about this, apart from the dressmaker with her pins?

At another point Beauvoir observes:

Many young girls suffer because their calves are too sturdy, because their breasts are either too slight or too heavy, because their hips are skinny, or on account of a wart; or else, they fear some secret deformity:

Every young girl carries within herself all sorts of absurd fears which she hardly dares admit to herself, says Stekel. No one would believe how many young girls suffer from the obsession of being physically abnormal and secretly torment themselves because they can't be sure of being built in the usual way. One young girl for example believed her "lower opening" was in the wrong place. She thought sexual intercourse took place through the navel, and was unhappy because her navel was closed and she couldn't get her finger into it. Another believed she was a hermaphrodite. Yet another thought she was crippled and would never be able to have sexual relations. ${ }^{102}$

101 “Je souffrais d'un sentiment d'infériorité physique entretenu par des critiques incessantes à la maison.... Ma mère dans sa vanité exagérée voulait toujours me voir particulièrement à mon avantage et elle avait toujours un tas de détails à faire remarquer à la couturière pour dissimuler mes défauts: les épaules tombantes, les hanches trop fortes, le derrière trop plat, les seins trop pleins, etc. Ayant eu le cou gonflé pendant des années, il ne m'était pas permis d'avoir le cou nu.... Je me vexai surtout à cause de mes pieds qui pendant ma puberté était très laids et on m'agaçait à cause de ma façon de marcher.... Il y avait certainement quelque chose de vrai dans tout cela, mais on mavait rendue tellement malheureuse, et surtout comme 'backfisch' et j'étais parfois tellement intimidée que je ne savais plus du tout comment me tenir; si je rencontrais quelqu'un, ma première idée était toujours 'si seulement je pouvais cacher mes pieds'” ( $D S$ 2:67). Ellipses in original.

102 "[B]eaucoup de jeunes filles souffrent de ces mollets trop robustes, de ces seins trop discrets ou trop lourds, de ces hanches maigres, de cette verrue: ou bien, elles craignent quelque malformation secrète

Toute jeune fille porte en elle toutes sortes de craintes ridicules qu'elle ose à peine s'avouer, dit Stekel. On ne saurait croire combien de jeunes filles souffrent de l'obsession d'être physiquement anormales et se tourmentent en secret parce qu'elles ne peuvent pas avoir la certitude d'être normalement bâties. Une jeune fille par exemple croyait que son 'ouverture inférieure' n'était pas à sa place. Elle avait cru que le commerce sexuel se faisait à travers le nombril. Elle était malheureuse que son nombril soit fermé et qu'elle ne puisse y enfoncer son doigt. Une autre se croyait hermaphrodite. Une autre se croyait estropiée et incapable d'avoir jamais de rapports sexuels" (DS 160-61). 
Nothing natural here, and no indication that these obsessions are especially delusional: they result from an absence of accurate information, and from a lack of openness.

How do these examples bear on the claim, which is still being made, that Simone de Beauvoir did not like the female body?103 They show something rather different: her understanding that most women did not like their own bodies, and her grasp of the reasons why.

Fourth: Beauvoir also includes two of Stekel's many accounts of the sexual molestation of children. Here again Stekel was in advance of Freud: it would be too simple to say Freud thought sexual abuse never occurred, but he treated such memories with skepticism, as screens for repressed desire for the father. Stekel was more straightforward. "Grandfathers among others are often very dangerous ...":

I was fifteen. The day before the funeral, my grandfather came to sleep at our house. The next day, my mother had already gotten out of bed, he asked me if he couldn't come into my bed to play with me; I got up immediately without answering him .... I began to be afraid of men, recounts a woman.

Another young girl remembers suffering a severe shock at the age of eight or ten years old when her grandfather, an old man of seventy, groped her genitals. He took her on his lap and slid his finger into her vagina. The child felt a boundless distress [une immense angoisse] but never dared to speak of it. Since that time she has been very afraid of all that is sexual. ${ }^{104}$

103 Patricia Moynagh usefully summarized this controversy in 2006 as follows: "For the opinion that Beauvoir adopted a negative view of women's bodies, see, for example, O'Brien, The Politics of Reproduction, which claims that The Second Sex undermines women's capacity to reproduce. Similarly, Moira Gatens has taken Beauvoir to task for presupposing that women 'simply are absolutely Other' due to female biology. (See Gatens, Feminism and Philosophy, 27.) Elizabeth Grosz claims that Beauvoir treats the body as a thing, unlike other feminists such as Irigaray, Cixous, Spivak, Wittig, Butler, and many others who are concerned with the lived body. That Beauvoir treats the body as a thing is simply not true, though she says we may experience it as such and indeed this may be inevitable" (Moynagh, "Beauvoir on Lived Reality, Exemplary Validity, and a Method for Political Thought," 28). See below for further discussion.

104 Parshley includes most of this one, but reads, "tampered with her genitals, inserting his finger. The child felt severe pain but was afraid to speak of the incident." "Pain" is one solution to the hard-to-translate "angoisse," which can mean both anguish and anxiety; it suggests physical pain, which seems likely enough, though it's not what the text says. "On trouvera des récits de telles expériences dans L'asphyxie de Violette Leduc, dans La haine 
The doctor went outside the clinic and saw that men really were attacking her. ${ }^{105}$

However, it's in the chapter on sexual initiation that Stekel really comes into his own. If you add that chapter together with the one on "La femme mariée" (The Married Woman), where the issue of sexual initiation is reprised, you find a total of twenty-one examples of horrible first experiences of sex, of which nine end in hospitalization or suicide, and all result in ruining the woman's enjoyment of sex thereafter. And these are just Stekel's examples: Beauvoir has many more. Frigidity can result from an awful experience of the marriage bed:

Stekel mentions some gripping examples on this point....

A woman of thirty-six has suffered for fourteen years from lower back pains so unbearable that she has to take to her bed for many weeks.... She felt these violent pains for the first time on her wedding night. During the defloration, which was exceedingly painful, her husband cried out: "You deceived me, you're no longer a virgin...." The pain is the fixation of this unpleasant scene. This illness is the husband's punishment, as he has had to spend huge sums for her numerous cures.... This woman remained numb [insensible] during her wedding night and she has remained so

maternelle de S. de Tervagnes et L'orange bleue de Yassu Gauclère. Stekel estime que les grands-pères entre autres sont souvent très dangereux.

J'avais quinze ans. La veille de l'enterrement, mon grand-père était venu coucher à la maison. Le lendemain, ma mère s'était déjà levée, il me demanda s'il ne pourrait pas venir dans mon lit pour jouer avec moi; je me levai immédiatement sans lui répondre.... Je commençai à avoir peur des hommes, raconte une femme.

Une autre jeune fille se rappelle avoir subi un choc sérieux à lâge de huit ou dix ans quand son grand-père, un vieillard de soixante-dix ans, avait tripoté ses organes génitaux. Il l'avait prise sur ses genoux en glissant son doigt dans son vagin. L'enfant avait senti une immense angoisse mais n'osa pourtant jamais en parler. Depuis ce temps elle a eu très peur de tout ce qui est sexuel" ( $D S$ 2:79-80).

105 Beauvoir's use of Stekel thus brings her closer to the position on childhood trauma now associated with Alice Miller and Jeffrey Moussaieff Masson: stories of childhood abuse, from those Freud discounted in his own practice to those we hear today, were real, they really happened, and when psychoanalytic theory becomes a means to deny this or explain it away, psychoanalysis itself becomes a form of abuse. See Miller, Thou Shalt Not Be Aware: Society's Betrayal of the Child, and Masson, The Assault on Truth: Freud's Suppression of the Seduction Hypothesis; see also Janet Malcolm, In the Freud Archives. That Beauvoir was concerned, in a way we would consider political, with the abuse of women and girls, is suggested by the account she gives in La force de l'âge of her sympathy toward a young girl, Violette Nozières, who was accused of poisoning her abusive father, and her outrage at the hypocrisy of the judges and press who in her view "s'employèrent à étouffer la vérité" (busied themselves hushing up the truth) (FA 153-54). This would have happened in 1933 . 
throughout the time of her marriage.... Her wedding night was a terrible trauma determining her whole future life.

A young woman consults me for various nervous troubles and especially an absolute frigidity.... On the wedding night, her husband uncovered her and cried out, "Oh! What short, thick legs you have!" Then he attempted coitus, which left her perfectly numb [insensible] and caused her only pain.... She knew quite well that the insult on her wedding night was the cause of her frigidity.

Another frigid woman recounts that "during her wedding night, her husband profoundly insulted her: while watching her undress, he said, "My God but you're skinny!" Then he made up his mind to caress her. For her, the moment was unforgettable and horrible. What brutality!

Mrs. Z.W. is also completely frigid. The great trauma of her wedding night was that her husband said to her, after the first intercourse, "You have a great big hole, you deceived me."106

Mrs. H.N. ...., raised very puritanically, trembled at the thought of her wedding night. Her husband undressed her almost with violence without permitting her to go to bed. He took off his own clothes, demanding that she look at him nude and admire his penis. She hid her face in her hands. Then he exclaimed, "Why didn't you stay home, you stupid idiot [espèce

106 "Stekel rapporte à ce propos des exemples saisissants:

Une dame de trente-six ans souffre depuis quatorze ans de douleurs lombaires si insupportables qu'elle doit garder le lit pendant plusieurs semaines.... Elle a ressenti cette violente douleur pour la première fois au cours de sa nuit de noces. Au cours de la défloration qui avait été excessivement douloureuse, son mari s'était écrié: ‘Tu m’as trompé, tu n'es plus vierge....' La douleur est la fixation de cette scène pénible. Cette maladie est le châtiment du mari qui a dû dépenser de grosses sommes pour ses innombrables cures.... Cette femme est restée insensible pendant la nuit de noces et elle l'est restée pendant tout le temps de son mariage.... La nuit de noces fut pour elle un affreux traumatisme déterminant toute sa vie future.

Une jeune femme me consulte pour plusieurs troubles nerveux et surtout une frigidité absolue.... Dans la nuit de noces, son mari après l'avoir découverte se serait écrié: 'Oh! comme tu as les jambes courtes et épaisses!' Ensuite, il tenta le coït qui la laissa parfaitement insensible et ne lui causa que des douleurs.... Elle savait très bien que c'était l'offense de sa nuit de noces qui était la cause de sa frigidité.

Une autre femme frigide raconte que 'pendant sa nuit de noces, son mari l'aurait profondément offensée: en la voyant se déshabiller, il aurait dit: 'Mon Dieu que tu es maigre!' Ensuite, il se serait décidé à la caresser. Pour elle, ce moment aurait été inoubliable et horrible. Quelle brutalité!

Mme. Z.W. est également complètement frigide. Le grand traumatisme de la nuit de noces fut que son mari lui aurait dit après le premier coït: 'Tu as un grand trou, tu m'as trompé"' (DS 2:161-62). 
de gourde]! Finally, he threw her on the bed and brutally deflowered her. Naturally she remained frigid forever. ${ }^{107}$

Trauma can also result from the husband's impotence: she cites an example from Freud—as summarized by Stekel.

A patient [une malade] had the habit of running from one room to another room in the middle of which stood a table. Then she would arrange the tablecloth in a certain way, call the maid to approach the table, and then dismiss her.... When she tried to explain this obsession, she remembered that the cloth had a nasty stain and that she would arrange it each time so that the stain would become obvious to the maid.... It was all a reproduction of the wedding night, when the husband had showed himself less than virile. He ran from his room to hers a thousand times to try again. Embarrassed about the maid who would have to make the beds, he poured out some red ink on the sheet to make her believe there was blood. ${ }^{108}$

Or, personal situation, conditioned by social milieu, can engender frigidity:

Miss G. S. ... had given herself to a man, expecting that he would marry her, but insisting on the fact "that she didn't care for marriage, she didn't want to tie herself down." She played at being the free woman. In truth, she was a slave to morality, like her whole family. But her lover believed her and never mentioned marriage. Her stubbornness became more and more intense until she became numb. When he finally asked her to marry

107 "Mme. H.N.... élevée très pudiquement tremblait à l'idée de sa nuit de noces. Son mari la déshabilla presque avec violence sans lui permettre de se coucher. Il se débarrassa de ses vêtements en lui demandant de le regarder nu et d'admirer son pénis. Elle dissimula sa figure dans ses mains. Alors il s'exclama: 'Pourquoi n'est-tu pas restée chez toi, espèce de gourde!' Ensuite, il la jeta sur le lit et la déflora brutalement. Naturellement, elle demeura à jamais frigide" (DS 2:248).

108 "Une malade avait l'habitude de courir d'une chambre vers une autre au milieu de laquelle se trouvait une table. Elle arrangeait alors la nappe d'une certaine façon, sonnait la bonne qui devait s'approcher de la table et la congédiait.... Quand elle essaya d'expliquer cette obsession, elle se rappela que cette couverture avait une vilaine tache et qu'elle l'arrangeait chaque fois de façon que la tache devait sauter aux yeux de la bonne.... Le tout était une reproduction de la nuit de noces où le mari ne s'était pas montré viril. Il accourut mille fois de sa chambre dans la sienne pour essayer de nouveau. Ayant honte de la bonne qui devait faire les lits, il versa de l'encre rouge sur le drap pour lui faire croire qu'il y avait du sang" (DS 2:250). 
him, she revenged herself by declaring her lack of feeling, no longer wishing to hear of a union....

A young girl of seventeen had a love-affair with a man in which she took intense pleasure. Pregnant at nineteen, she asked her lover to marry her; he was indecisive and advised her to have an abortion, which she refused to do. After three weeks, he declared that he was ready to marry her and she became his wife. But she never forgave him those three weeks of torture and became frigid...

Mrs. N.M. ... learns that two days after her wedding her husband went to see an old mistress. The orgasm she had had before that disappeared forever. ${ }^{109}$

What emerges from this sorry litany? For one thing, Beauvoir adds to her indictment of how women are brought up, an indictment of how men behave toward them through physical and verbal brutality or simply by not being up to the task (perhaps because men's education, too, is faulty). To show how badly men treat women under patriarchy was not really Stekel's overall point; but at the end of the day, what we have is a catalogue of male sexual insensitivity to rival The Golden Notebook.

109 “Mlle. G.S.... s'était donnée à un homme en attendant qu'il l'épouse, mais en insistant sur le fait 'qu'elle ne tenait pas à un mariage, qu'elle ne voulait pas se lier.' Elle jouait à la femme libre. En vérité, elle était esclave de la morale comme toute sa famille. Mais son amant la croyait et ne parlait jamais de mariage. Son opiniâtreté s'intensifiait de plus en plus jusqu'à ce qu'elle devînt insensible. Quand il la demanda enfin en mariage, elle se vengea en lui avouant son anesthésie et en ne voulant plus entendre parler d'une union. Elle ne voulait plus être heureuse. Elle avait trop attendu.... Elle se dévorait de jalousie et attendait anxieusement le jour de sa demande pour la refuser orgueilleusement. Ensuite, elle voulut se suicider uniquement pour punir son amant avec raffinement.

Une femme qui jusque-là avait eu du plaisir avec son mari, mais très jalouse, s'imagine pendant une maladie que son mari la trompe. En rentrant chez elle, elle décide de rester froide avec son mari. Jamais plus elle ne devrait être excitée par lui puisqu'il ne l'estimait pas et n'usait d'elle qu'en cas de besoin. Depuis son retour elle était frigide. Au début elle se servait de petits trucs pour ne pas être excitée. Elle se représentait son mari faisant la cour à son amie. Mais bientôt l'orgasme fut remplacé par des douleurs....

Une jeune fille de dix-sept ans avait une liaison avec un homme et y prenait un intense plaisir. Enceinte à dix-neuf ans, elle demanda à son amant de l'épouser: il fut indécis et lui conseilla de se faire avorter, ce qu'elle refusa. Après trois semaines, il se déclara prêt à l'épouser et elle devint sa femme. Mais elle ne lui pardonna jamais ces trois semaines de tourment et devint frigide. [...]

Mrs. N.M.... apprend que son mari, deux jours après son mariage, est allé voir une ancienne maîtresse. L'orgasme qu'elle avait auparavant disparut à jamais" (DS 1:179). 
Does it "date" The Second Sex that it has no chapter on violence against women? Not so much, in my opinion. It is true that "rape" does not figure in the table of contents, so if you're looking quickly for an excerpt on the topic to include on your Intro syllabus you won't find one. What you will find, though, in the chapter on "sexual initiation," is the statement that women's first experience of sex is always more or less of "un viol," a rape, ${ }^{110}$ and a quotation from Havelock Ellis to the effect that there is more rape inside of marriage than out of it." ${ }^{111}$ Perhaps she would not have been uncomfortable with the idea of a "rape continuum." There are moments where she almost sounds like Andrea Dworkin. ${ }^{112}$

But insofar as she subsumes rape, including violent rape, under a broader category I've been calling "bad sex," she is departing from a feminist view that was orthodox for many years: that rape should be understood not as sex but as violence. ${ }^{113}$ This may raise red flags for those who remember a shallow, antifeminist backlash book by Katie Roiphe, The Morning After: Sex, Fear, and Feminism on Campus (1993), which argued that there was no such thing as date rape, just "bad sex."114 It was Roiphe, I think, who started the backlash against what she called "victim feminism" (such as Take Back the Night marches). That approach was, to put it mildly, unhelpful to grass-roots activists on campuses (where rape remains epidemic); the uptake of the critique of "victim feminism" from within feminism, by Naomi Wolf and others, seems to me a further step backward.115 This really is not what Beauvoir is doing, though: far from dismissing other problems as "just bad sex," her claim is that what I'm calling

\footnotetext{
$110 \quad D S_{2: 163}$.

$111 D S$ 2:248.

112 For a fascinating application of Beauvoir's phenomenology to the problem of violence against women, see now Fiona Vera-Gray, Men's Intrusion, Women's Embodiment: A Critical Analysis of Street Harassment.

113 I have vivid memories of a woman named Linda Morrison, at a training for campus advocates in the 1990s, raising a rolling pin high over her head and saying, "if I hit you over the head with this, nobody in their right mind would say, wow, Linda Morrison's baking. So just because a penis and a vagina are involved...."

114 Depressingly similar arguments appear periodically in the backlash against student campus activism, for instance, the 2014 Twitter war between \#notallmen and \#yesallwomen.

115 Naomi Wolf, Fire With Fire: The New Female Power and How to Use It (1994). For a strong analysis, see Alison Phipps, Politics of the Body. It's hard not to notice that criticisms of women's studies programs for "living in the past," and denunciations of "left melancholy" as if that were a character flaw-which is not at all what Walter Benjamin meant, by the way-followed soon after Roiphe's fifteen minutes of fame, and tended in the same direction. See for instance Wendy Brown, States of Injury: Power and Freedom in Late Modernity.
} 
bad sex is in itself a manifestation of male power, and a very bad problem indeed.

But is she then saying - and many have claimed this - that something is wrong with women? Did Beauvoir hate the female body, and idealize the male body and men more generally? Quite close to passages I've been discussing is a section that has been key in those arguments and that I admit I myself have never loved. It connects back to the idea of women's sexual arousal as simultaneous attraction and repulsion - the idea Beauvoir advanced as something all the psychoanalysts, including Stekel, had failed to understand or seemed not to know.

Feminine sex desire $[r u t]$ is the soft throbbing of a mollusk. Whereas man is impetuous, woman is only impatient; her expectation can become ardent without ceasing to be passive; man dives upon his prey like the eagle and the hawk; woman lies in wait like a carnivorous plant, a swamp which insects and children sink into. She is suction, leech-like suction, inhalation, she is pitch and glue, a passive appeal [appel], insinuating and viscous: thus, at least, she vaguely feels herself to be. This is why there is in her not only resistance against the male who claims to make her submit, but also interior conflict....16

Commentators, most especially Michèle Le Dœuff, have noted that the language of "holes and slime" is Sartrean language, and have found it problematic here. I certainly agree that as a description of what women's body is, in the initself, essence, Being sense of "is," this would clearly be unacceptable. (I am not a mollusk. Do not call me a mollusk.) ${ }^{117}$ But is this such a description? Suppose

116 Toril Moi's translation of this passage (Making of an Intellectual Woman, 168) helped me here, but I have modified it slightly. "Le rut féminin, c'est la molle palpitation d'un coquillage; tandis que l'homme a de l'impétuosité, la femme n'a que de l'impatience: son attente peut devenir ardente sans cesser d'être passive; l'homme fond sur sa proie comme l'aigle et le milan; elle guette comme la plante carnivore, le marécage où insectes et enfants s'enlisent; elle est succion, ventouse, humeuse, elle est poix et glu, un appel immobile, insinuant et visqueux: du moins est-ce ainsi que sourdement elle se sent. C'est pourquoi, il n'y a pas seulement en elle résistance contre le mâle qui prétend la soumettre, mais aussi conflit intérieur. Aux tabous, aux inhibitions provenant de son éducation et de la société se superposent des dégoûts, des refus qui ont leur source dans l'expérience érotique ellemême: les uns et les autres se renforcent mutuellement si bien qu'après le premier coït la femme est très souvent plus révoltée qu'auparavant contre son destin sexuel" ( $D S$ 2:167).

117 I started to write, I am not viscous, but then again ... OK, I took a shower, so I'm not viscous right now. But surely if one is not at least somewhat viscous during intercourse, it's going to hurt like hell? 
we read this paragraph in the light of her statement (early in Volume 1) that "the body is not a thing, it is a situation,"118 and note the end of its penultimate sentence: "du moins est-ce ainsi que sourdement elle se sent" (thus, at least, she vaguely feels herself to be), "sourdement" meaning, literally, "deaf-ly." Is it not, rather, a description of how it might feel like for a young girl who has been taught to hate and fear her body to be waiting in bed for a man she only sort of knows, to come and do, she's not exactly sure what, to her-although she knows she wants him to do something ... As a phenomenological account of that lived experience (which is not everybody's, not always, need not be, should not be) it may actually be sort of ... recognizable?119

Now, the challenge of reading volume 2 is keeping one's mind fixed on the governing theoretical language that opens it: "I do not refer to any archetype, or any unchangeable essence; after most of my statements, one must understand [sous-entendre] 'under present conditions of education and society."'120 Bearing that in mind, and in the proximate context of rapes, near rapes, insults, misinformation, and general misery with which Beauvoir has just loaded us, it seems to me better to see the "mollusk" section as a description of a woman's experience of her body as conditioned by patriarchy, and not in a shallow way.

If so, this section can be read to show that women's sexual misery is a nontrivial aspect of their oppression, a crime, something worth discussing in order to change it. Part of being a woman is experiencing your own body as loathsome to yourself. In a culture where women still starve themselves, cut themselves, rot out their insides with induced vomiting — all phenomena Beauvoir explicitly discusses, by the way—can we really claim that this is dated?

$118 D S$ 1:73. "[D]ans la perspective que j'adopte—celle de Heidegger, de Sartre, de MerleauPonty-si le corps n'est pas une chose, il est une situation: c'est notre prise sur le monde et l'esquisse de nos projets."

119 Marso and Moynagh make the point that Beauvoir generally "makes a vital distinction between ontological claims ... and phenomenological claims" (Simone de Beauvoir's Political Thinking, 4). For a fuller explanation of the phenomenological background see Sara Heinämaa, Toward a Phenomenology of Sexual Difference: Husserl, Merleau-Ponty, Beauvoir. See also now Jennifer McWeeny, "The Second Sex of Consciousness."

120 'When I use the words 'woman' or 'feminine' obviously I am not referring to any archetype or any unchangeable essence; after most of my claims the reader should infer 'in the current state of education and social custom.' The point is not to set forth some eternal Truths, but to describe the common background from which every singular woman's existence takes off." [Quand j'emploie les mots 'femme' ou 'féminin' je ne me réfère évidemment à aucun archétype, à aucune immuable essence; après la plupart de mes affirmations il faut sous-entendre 'dans l'état actuel de l'éducation et des mœurs.' Il ne s'agit pas ici d'énoncer des vérités éternelles mais de décrire le fond commun sur lequel s'enlève toute existence féminine singulière $(D S$ 2:9).] 
Fifth: Stekel's examples as Beauvoir deploys them provide a powerful critique of bourgeois marriage. He did not mean to do this. She meant to do this. The critique is undertaken directly in the name of sexual pleasure. She meant this, too. The young girl, she says, is sold a bill of goods in the name of bourgeois "bonheur"; sex can, indeed, be an excellent thing; but "the principle of marriage is obscene." Following closely on a page-long account of a woman's disappointment on her wedding night, owing to the husband's timidity and inexperience, Beauvoir writes:

The difficulties of the early experiences are easily overcome, when love or desire draws a complete consent from both partners. Physical love draws its power and dignity from the joy the lovers give and receive in the mutual consciousness of their freedom. Nothing they do can then be shameful, since neither of them is submitting to it: it is generously desired by both of them. But the principle of marriage is obscene because it transforms an exchange which should be founded on a spontaneous impulse into rights and duties; it gives the bodies an instrumental, thus degrading character in dooming them to take hold of their generality. ${ }^{121}$

The abstraction "generality" is part of an argument she is carrying on with Hegel, but that need not detain us here, since what is at stake is not at all abstract. The passage continues: "The husband is often chilled by the thought that he is carrying out a duty, and the wife feels shame, finding herself at the mercy of someone exercising his rights." ${ }^{122}$ Sex is good but only when it is free. As she has said much earlier, "[s]exual instinct cannot be regulated ... it will not let itself be integrated into the social, ${ }^{123}$ because there is in eroticism a revolt of the instant against time, of the individual against the universal."124 But

121 "Les difficultés des premières expériences sont aisément surmontées si l'amour ou le désir arrachent aux deux partenaires un total consentement; de la joie que se donnent et prennent les amants dans la conscience réciproque de leur liberté, l'amour physique tire sa puissance et sa dignité; alors aucune de leurs pratiques n'est infâme puisque, pour aucun, elle n'est subie mais généreusement voulue. Mais le principe du mariage est obscène parce qu'il transforme en droits et devoirs un échange qui doit être fondé sur un élan spontané; il donne aux corps en les vouant à se saisir dans leur généralité un caractère instrumental, donc dégradant" ( $D S$ 2:254-55).

122 "[L]e mari est souvent glacé par l'idée qu'il accomplit un devoir, et la femme a honte de se sentir livrée à quelqu'un qui exerce sur elle un droit" ( $D S$ 2:255).

123 "Le social." We might say "social system," or just "it will not let itself be socialized."

124 "[O]n ne peut réglementer l'instinct sexuel ... il ne se laisse pas intégrer au social parce qu'il y a dans l'érotisme une révolte de l'instant contre le temps, de l'individuel contre l'universel" (DS 1:103-4). She says something quite similar in her essay on Sade; and she 
when eroticism is pressed into service to mean, or to support, something other than itself-the state, bourgeois values, an economic bargain, or even an enduring relationship - the revolutionary character of free eroticism cannot survive. And, as she continues to describe at some length, it is not just that such relations should (theoretically) not be satisfying, they actually and concretely are not satisfying, at least after a time.

I agree with commentators who have read these passages, and a few others, as signs of a utopian strain in Beauvoir's writing about the possibilities of sex and love; both Debra Bergoffen and Karen Vintges have emphasized Beauvoir's development of a sexual ethics of mutual recognition and reciprocity between equals, which is particularly salient when contrasted with Sartre's much grimmer vision of human relationship and his devaluation of emotion. ${ }^{125}$ For instance, at the end of her chapter on "sexual initiation": "the normal and happy flowering of female eroticism" requires that "woman succeed in surmounting her passivity and in establishing with her partner a relationship of reciprocity."126 But Vintges and Bergoffen are concerned with love and not with sex as suchVintges calls her chapter "A Place for Love" - and both tend to elide the part of Beauvoir's discussion that is specifically sexual, sexual in a concrete and embodied way. Vintges discusses the frigid woman only as she appears in Lêtre et le néant, and Bergoffen never mentions frigidity at all.

Beauvoir certainly did take the view that if and when sexuality was not rooted in a traditional economy with the man as taking and the woman as giving

drew the ethical reflection in an early diary, as Margaret Simons underlines: "The diary passage (for May 6, 1927) reads in part 'I had just seen Barbier again .... [O]ne instant I held in my hands an entirely new life .... The horror of the definitive choice, is that it engages not only the self of today, but that of tomorrow, which is why basically marriage is immoral" (Beauvoir and The Second Sex: Feminism, Race, and the Origins of Existentialism, 195). See also Altman, "Beauvoir and the Sexual Revolution."

125 A similar argument was advanced by Barbara Andrew in her paper "How Love Allows One To Be Free and Vice Versa." See Bergoffen, The Philosophy of Simone de Beauvoir: Gendered Phenomenologies, Erotic Generosities, and Vintges, Philosophy as Passion, although Vintges notes that Beauvoir "retains the barb of Sartre's thinking": in general, her discussion is more nuanced and textually grounded than Bergoffen's. See also Bauer, Beauvoir, Philosophy, \& Feminism, 224-37.

126 "Cet épanouissement suppose que-dans l'amour, la tendresse, la sensualité-la femme réussisse à surmonter sa passivité et à établir avec son partenaire un rapport de réciprocité" (DS 2:189). 
(or providing a service), and provided the sexual act itself could be spontaneous and autonomous, it was of enormous value, and that the changes to the world that would be necessary for this to come about were changes worth working for. The passages where Beauvoir discusses this are lovely. But they are tantalizingly brief, and they are rare; whereas the discussions of bad sex are all-too-frequent, all-too-long, all-too-ugly, and very concrete. Bergoffen herself does not claim otherwise; she says Beauvoir "speaks in more than one voice-a voice of the project that appeals to traditional Marxist-existentialist analyses, and a voice that challenges the ethic of the project by calling on the categories of generosity, the gift, and the erotic to liberate us from the perversions of patriarchal gender."127 Within philosophy today this may count as a brave claim. But we should think about what we do when we use euphemisms like "erotic" and "embodiment" and the "bond" - a word I do not think ever appears in The Second Sex - to talk about, well, fucking, and orgasm, and being made to feel like a thing rather than a person. Bergoffen's epilogue notes that

a book dedicated to the un-thought of Beauvoir's work is a paradoxical enterprise. On the one hand, the point of the book is to assert the presence of a thinking that is integral to the body of Beauvoir's philosophy. On the other hand, it recognizes that the thinking it points to is barely acknowledged by Beauvoir herself.

I do not pretend to understand why the category of the erotic, the revised description of intentionality, the paradigm of generosity, and the ethic of the gift remains on the margins of Beauvoir's work. ${ }^{128}$

Well. There is a broader point to be made here about the tension between two sorts of approaches philosophers take to the work of earlier philosophers. One kind, often disparaged as merely "history of philosophy," "not really philosophy," undertakes to provide an accurate, historicized account of what the earlier writer was doing, to represent their views fully and fairly even when disagreeing with them. In the other kind, a small amount (sometimes a very small amount) of source material serves as stimulus or jumping-off point for the later writer's own creative and speculative thought. Both can be productive for feminism, but the latter can sometimes leave one feeling faintly crazy. ("Did she read the same book I read? Is there something wrong with my head?") Having read a number of books with titles like Hegel's Philosophy of $X$ which might more accurately have been titled Rhapsody on a Theme by Hegel, I appreciate

127 Bergoffen, Philosophy of Beauvoir, 110.

128 Ibid., 221. 
Bergoffen's honest epilogue, but I admit to finding this approach to scholarship methodologically foreign — and somewhat perverse.

And I especially have trouble following Bergoffen's slippage from "an ethic that figures our desire for recognition according to the paradigms of generosity and the gift" to the idea that Beauvoir somehow might see (certain kinds of) marriages as worth celebrating after all. ${ }^{129}$ This is informed by what I can only call wishful thinking. One may disagree with Beauvoir, but what she said was "the principle of marriage is obscene," and that is, I believe, what she meant. ${ }^{130}$

(Is the feminist critique of marriage itself dated? It is true that one rarely hears it in public any more, even from queers. One has to be so careful not to question any woman's choice. "There's nothing to be gained by offending people." Is there then nothing to be lost by being afraid of offending people?)

Perhaps here is the place to say that Beauvoir's focus on sexuality, which I've been emphasizing here, is not in contradiction to the fundamentally materialist analysis that undergirds The Second Sex. Sexuality and economics are tightly intertwined for her, or rather, bad sex and economics are intertwined. ${ }^{131}$ What ruins sex for women, even after the difficulties of initiation have been overcome (and incidentally also ruins sex for men) is that it is embedded in a system of economic relationships-chiefly marriage, but her discussion is more wide-ranging (see for example her chapters on the prostitute, and on the woman in love, who is often a kept mistress rather than a wife). As long as some or most women derive their income from marriage, the economic lot of even those women who do not marry is worsened: wages for "women's work" are depressed; the temptation to add to one's low income by taking money from men for sex, directly or indirectly ("se faire aider") understandably becomes greater; this in turn influences the already unpleasant and sexualized conditions of the workplace; all of which makes marriage, even where not women's only choice, more attractive than it would otherwise be, thus perpetuating the whole system, da capo al fine. (If at this point you're saying, wait,

129 Ibid., 7 .

130 To be fair, Parshley's version- "marriage is obscene in principle" - somewhat weakens the axiomatic force of Beauvoir's claim in English, as a thing could be bad "in principle" ("in theory") but OK "in practice." Parshley's sentence can be read along those lines, but if Beauvoir had meant this, she would have said something like "en principe, le mariage est obscène."

131 One might contrast this to "The Myth of the Vaginal Orgasm," where Koedt describes the reasons women sleep with men, fake orgasm, etc., as psychological; she doesn't discuss the economic or other pragmatic factors that frame women's sexual choices. Adrienne Rich would later restore the economic analysis to the discussion of sex in "Compulsory Heterosexuality and Lesbian Existence." 
they told me Beauvoir was a bourgeois liberal feminist with no class analysis ... yes, they probably did tell you that. You have to read the book. $)^{132}$

The link forged between sex and money by the marriage system is harmful to women in at least two ways. First, because it disadvantages them with respect to men (men have power over women in bed because of all the ways men have power over women outside the bed); but second, because sex is not the sort of thing about which one should engage in economic relationships, buying, exchange. It amounts to buying and selling the body, buying and selling what is precious about individual subjectivity. That's why the utopian sentence about the instant and the individual occurs in the chapter on Marx and Engels, rather than in the chapter on Freud. Even if the bargain of marriage could somehow be made fairer (for instance, suppose the state paid women wages for housework including sexual services), that would not satisfy Beauvoir's objection. She remains outraged by the idea of sexuality as a "service," the idea that it should enter into a nexus of economic exchange at all.

Outrage is not too strong a word. We learn from Mémoires d'une jeune fille rangée that it was Beauvoir's best friend, Zaza, who first made the connection for her, pointing out that there was no difference between bourgeois marriage and prostitution, except for the amounts of money involved. Zaza figured this out on her own, without having taken Feminist Theory, as her mother was trotting her around in hopes of arranging a money marriage, while forbidding her to have any contact (even through letters) with the man she actually loved. Beauvoir attributed her friend's tragic death to the frustration of both spirit and body, the contradictions between Zaza's lucidity about her individual needs and her loyalty to her mother's bourgeois world; I think she kept faith with that moment of disgust and insight her whole life. The last line of Mémoires d'une jeune fille rangée reads: "Together we had fought against the dank quicksands of the destiny which lay in wait for her, and for a long time I felt that I had bought my freedom with her death." ${ }^{\prime 33}$ This sounds both melodramatic and romantic, I know, but Toril Moi has observed that existentialism is a melodramatic philosophy, and second wave feminism, at least in the United States, was (despite its attack on the selling of romance) in some ways a romantic movement, hoping to recover the real body underneath the makeup and the trappings, to find the real love (heterosexual or otherwise) that at least potentially lay on the other side of revolution, once the "power trips" had been

132 I'll have more to say about Beauvoir's materialism in chapter 3.

133 "Ensemble nous avions lutté contre le destin fangeux qui nous guettait et j'ai pensé longtemps que j'avais payé ma liberté de sa mort" $(M J F R, 503)$. 
gotten out of the way: the hope that (as Foucault would rather snidely parody such discourses of liberation) "tomorrow sex will be good again."134

Or perhaps the critique of marriage would have struck Beauvoir even without Zaza's mediation. In Une mort très douce, she writes about her own mother: "Her case would have been enough to convince me that bourgeois marriage was an unnatural institution." 135

So in Beauvoir's chapter about marriage, the discourse of frigidity was being deployed against the selling of bourgeois married happiness ("bonheur" was the code word, in her early diaries, for the possibility of marriage to her cousin, which while attractive in some ways would have put an end to her independence and her intellectual life). This connects to the crucial distinction in her introduction between "happiness" and "freedom," which is worth reading in its full context:

When we look through books about woman, we note that among the viewpoints most usually adopted is the perspective of the public good or the general interest. In truth, what each writer means by this is the interest of society as he wishes to maintain or establish it. As for us, we hold that there is no public good other than that which ensures the private good of citizens; we judge institutions by the concrete opportunities they provide for individuals. But we do not confuse the idea of private interest with the notion of happiness, another frequently-encountered point of view: aren't women in a harem happier than a woman voter? Isn't the housewife happier than the woman worker [l'ouvrière]? It's hard to really know what the word "happiness" means, much less what authentic values it may mask [recouvre]; there is no way to measure someone else's happiness [le bonheur d'autrui] and it is always easy to declare that the situation one wants to impose on them is a happy one: in particular, those whom one condemns to stagnation, one declares happy under the pretext that happiness is immobility.... [Happiness] is therefore a notion to which we will not refer. The perspective we adopt is that of existentialist ethics. Every subject poses himself concretely, by means of projects, as a transcendence; he accomplishes his freedom only by perpetually moving through and beyond it [dépassement] toward other freedoms; there is no justification for present existence save its expansion toward an

134 Foucault, History of Sexuality, 7 , in the discussion of "the speaker's benefit." For historical context, see Didier Eribon, "Michel Foucault's Histories of Sexuality."

135 "[Q]ue le mariage bourgeois soit une institution contre nature, son cas suffirait à m'en convaincre" (Une mort très douce, 51 ). 
infinitely open future. Each time transcendence falls back into immanence there is degradation from existence to "in itself," from freedom to facticity. This fall is a moral failing [faute] if the subject consents to it; if it is inflicted on the subject, it takes the shape of a frustration and an oppression; either way, it is an absolute evil. ${ }^{136}$

Here Beauvoir anticipates, and argues against, not just the functionalist objection that marriage (and the subjection of women more broadly) is a necessary pillar of civil society required to support the State, but also the criticism that many if not most women prefer to be married and actively seek happiness through marriage rather than through work and economic independence. They may well do so, but their complicity is only one more sign of their subordination. This point was well summarized by Shulamith Firestone from the perspective of 1970: "Why should a woman give up her precious seat in the cattle car for a bloody struggle she could not hope to win?"137 Slaves, and women under patriarchy, may be told by their masters that they are happy; they may put on a good show of being happy, and may even sincerely believe it. But that is no excuse for not freeing them. Consent is no defense.

To be sure, bringing Stekel to bear on a critique of bourgeois institutions involves reading him very much against the grain. His cases tend to have rather

${ }_{13}$ "Si nous passons en revue quelques-uns des ouvrages consacrés à la femme, nous voyons qu'un des points de vue le plus souvent adopté, c'est celui du bien public, de l'intérêt général; en vérité chacun entend par là l'intérêt de la société telle qu'il souhaite la maintenir ou l'établir. Nous estimons quant à nous qu'il n'y a d'autre bien public que celui qui assure le bien privé des citoyens; c'est du point de vue des chances concrètes données aux individus que nous jugeons les institutions. Mais nous ne confondons pas non plus l'idée d'intérêt privé avec celle de bonheur; c'est là un autre point de vue qu'on rencontre fréquemment; les femmes de harem ne sont-elles pas plus heureuses qu'une électrice? La ménagère n'est-elle pas plus heureuse que l'ouvrière? On ne sait trop que le mot bonheur signifie et encore moins quelles valeurs authentiques il recouvre; il n'y a aucune possibilité de mesurer le bonheur d'autrui et il est toujours facile de déclarer heureuse la situation qu'on veut lui imposer: ceux qu'on condamne à la stagnation en particulier, on les déclare heureux sous prétexte que le bonheur est immobilité. C'est donc une notion à laquelle nous ne nous référons pas. La perspective que nous adoptons, c'est celle de la morale existentialiste. Tout sujet se pose concrètement à travers des projets comme une transcendance; il n'accomplit sa liberté que par son perpétuel dépassement vers d'autres libertés; il n'y a d'autre justification de l'existence présente que son expansion vers un avenir indéfiniment ouvert. Chaque fois que la transcendance retombe en immanence il y a dégradation de l'existence en 'en soi,' de la liberté en facticité; cette chute est une faute morale si elle est consentie par le sujet; si elle lui est infligée, elle prend la figure d'une frustration et d'une oppression; elle est dans les deux cas un mal absolu ..." (DS 1:30-31).

Shulamith Firestone, The Dialectic of Sex: The Case for Feminist Revolution, 1. 
pat happy endings, like Dr. David Reuben's. Usually she omits these; at least once she includes it (in explaining why a woman frigid in her first marriage may be sexually happier with a lover or a second husband), but then notes, "[n] ot all affairs have fairy-tale endings." ${ }^{138}$

As I noted earlier, Stekel's name gradually drops out of the last third of volume 2, but "the frigid woman" does not. In the last sections, Beauvoir suggests that, in her misery and "rancune," the frigid woman, like the masochist, at least has a self, a "moi," and that rather than dissolving herself in eroticism, she affirms this "moi" through her resistance and may even achieve some lucidity in doing so. Apropos of the question of how "the independent woman" can satisfy her sexual desires, she considers the idea that women could simply purchase sexual services, as men have done for so long, but rejects this option as simply unsatisfying.

Masculine pride conceals the ambiguity of the erotic drama from the male: he lies to himself easily and spontaneously. Women are more easily humiliated, more sensitive, and also more lucid: she will only succeed in blinding herself at the cost of a more calculated bad faith. To buy herself a man, even if she could afford it, usually wouldn't seem satisfying to her. ${ }^{139}$

Perhaps the fact that women demand more from sexual encounters than men do is not actually a character flaw. Perhaps it is a sign of her greater potential for authenticity. In her essay on Sade, she says that "infliger une jouissance" (inflicting a pleasure, or inflicting an orgasm) can be a terrible thing, a terrible defeat for the object. ${ }^{140}$ Perhaps not to give in is better. The worst thing a woman can do is identify herself wholly with her status as object, as the narcissist and the woman in love do. It is better to be an unhappy person than a happy thing.

This all sounds very odd, doesn't it? So I was reassured to have my reading confirmed in the clearer context of an interview Beauvoir gave in 1976, that is, after she had identified herself with, and put her energies fully at the disposal of, the resurgent and vigorous Women's Liberation Movement.

138 "Toutes les liaisons ne s'achèvent pas ainsi en conte de fées" ( $D S$ 2:424).

139 "Lorgueil viril masque au mâle les équivoques du drame érotique: il se ment spontanément; plus facilement humiliée, plus susceptible, la femme est aussi plus lucide; elle ne réussira à s'aveugler qu'au prix d'une mauvaise foi plus rusée. S'acheter un mâle, à supposer qu'elle en ait les moyens, ne lui semblera généralement pas satisfaisant" ( $D S$ 2:6o8).

140 Faut-il brûler Sade?, 20. 
Alice Schwarzer: What role do you think sexuality, as it is understood today, plays in the oppression of women?

Simone de Beauvoir: I think that sexuality can be a dreadful trap. Some women become frigid - but that is not perhaps the worst thing that can happen to them. The worst is for women to find sexuality so enjoyable that they become more or less slaves to men — which can be another link in the chain shackling women to men.

Alice Schwarzer: If I understand you correctly, you see frigidity, given the current state of malaise created by the power relationships between men and women, as a more cautious and appropriate reaction, because it reflects this unease, and makes women less dependent on men?

Simone de Beauvoir: Exactly.141

Notice how neatly this reverses Sartre's use of the frigid woman to define bad faith. For Beauvoir, the narcissist is in bad faith, and the woman in love is in bad faith, and the lesbian may or may not be in bad faith depending on how she "assumes her situation" (see chapter 2 below); and we can extrapolate that a woman who fakes orgasm to hang on to her meal ticket might be in bad faith. But by the end of the book, the frigid woman is simply being honest, not just with her speech, but with her whole body, refusing to understand herself as only an object. ${ }^{142}$ This is the opposite of bad faith, this is authenticity. And this is politics.

However, in summarizing Beauvoir's use of Stekel, some troubling points remain so far unaccounted for by my analysis. In the chapter on "La mère," as I

\footnotetext{
141 Alice Schwarzer, Simone de Beauvoir Today: Conversations 1972-1982, 76-7.

142 Odd as this may sound, Beauvoir has some company here. Alison Moore mentions that Andrea Dworkin "ironically ... considered the invention of frigidity to be a lesser form of misogyny than the pornographic stereotypes of women as voracious nymphomaniacs, remarking, 'Perhaps this is a recognition, however perverse, that no one could possibly like or want what men do to women"' ("Invention of the UnSexual: Situating Frigidity in the History of Sexuality and in Feminist Thought," 182-83, quoting Dworkin, Pornography: Men Possessing Women, 179). Moore also mentions Elizabeth Grosz "paraphrasing Luce Irigaray: "The so-called "frigid woman" is precisely the woman whose pleasures do not fit neatly into the male-defined norms of sexual pleasure"” and then quoting Irigaray: "Many women believe they are 'frigid' and they are often told this is so. When a woman tells me she is 'frigid,' I laugh and tell her I don't know what this means" (182, quoting Grosz, Sexual Subversions: Three French Feminists, 133).
} 
mentioned earlier, she invokes his authority for the claim that morning sickness "always expresses a refusal of the child"; 143 she also takes up three bits from one of his case subjects who describes childbirth itself, and then breastfeeding, as sexually exciting, and describes this in a disturbingly erotic way. ${ }^{144}$ Perhaps she deploys these examples to undermine and interrupt a bourgeois construction of maternal "instinct" as the automatic, innocent, redemptive attribute of "la bonne pondeuse"? The "prevaricating woman" and her friend the "malade imaginaire" (his unsympathetic version of the "hysteric") are a much stronger presence in Stekel than in Beauvoir, but they are here, too.

Perhaps this is in line with Alice Schwarzer's observation that Beauvoir offered women an explanation, but never an excuse. ${ }^{145}$ On an abstract level, holding women responsible for their sexual feelings gives women back what later feminists would call agency. It's hard to feel easy in one's mind about this, remembering how mainstream American psychoanalysts blamed and abused women in the 1950s, ${ }^{146}$ and how closer to our own time Katie Roiphe used a similar line of reasoning to undermine women's right to say they have been sexually assaulted. But Beauvoir's version is considerably more complex. She recognizes a terrain of human lived experience that is neither wholly given nor wholly voluntary.

I am not sure subsequent work on this problem has brought us closer to solving it, theoretically or practically. In the early 1980 , Carole Vance explained that it was a mistake to confuse the view of sexuality as socially and culturally constructed with the view that sexuality is voluntary or easy to change. "The cultural analogue is useful here, for although human cultures are arbitrary in that behavior is learned and not intrinsic, anthropologists do not believe that entire cultures can transform themselves overnight, or that individuals socialized in one cultural tradition can acculturate at will."147 What feminists then (in the early days of what came to be called the "sex wars") were arguing about was not so much whether sexual patterning could be changed, but rather whether, and when, it made feminist sense to try to do so. There is a clear break between the way feminists talked about this in the early 1970s, when the point

\footnotetext{
$143 D S_{2: 353 .}$

$144 D S_{2: 363,371 .}$

145 Schwarzer, "Introduction," Simone de Beauvoir Today, 25, but the knife of the thought is clearer in the French: "Pour moi, la vie et l'œuvre de Simone de Beauvoir sont un défi lancé aux hommes et aux femmes. Car si les femmes peuvent trouver dans sa théorie l'explication de leur situation, elle ne pourra jamais leur servir d'excuse" (Simone de Beauvoir aujourd'hui: six entretiens, 26 ).

146 See e.g. Firestone, Dialectic of Sex, 66-72.

147 Carole Vance, "Introduction," Pleasure and Danger: Exploring Female Sexuality, 9.
} 
of consciousness raising was described as "starting to stop," collectively uncovering the patriarchal roots of one's inmost feelings in order to work at changing them, ${ }^{148}$ and the way most of us (I think) now approach, for instance, the task of increasing the feminist awareness of our students in introductory women's studies classes. One does not want to be prescriptive (indeed, that would be contradictory to the idea of consciousness-raising as authentic selftransformation) but I do think most of us, including most of the students, are at least vaguely hoping that something will change, internally as well as externally. (Isn't this what "awareness" means?) It is not always easy to find the middle ground between silencing or "shutting other people down," and the position caricatured in The Onion as: "Women Now Empowered By Everything A Woman Does."149 (Note the "now," which implies a "then.")

Plenty of examples support the view that Beauvoir's support and sympathy for whatever a woman did was not automatic. "There is some truth" in men's indictment of women's conduct, though "it is not dictated by her hormones" but molded by her situation. ${ }^{150}$ In the interests of balance, I'll include my least favorite example of Beauvoir's use of Stekel, from her chapter on "La vie de société" (Social Life): three really excessive stories of women who can only experience orgasm on the gynecologist's table. I hope Stekel made these up, and I'm not entirely sorry Parshley omitted most of this.

[T] hree-quarters of the men who are persecuted by erotomaniacs are doctors: it gives many women great exhibitionist pleasure to strip for a man.

I know some women, says Stekel, who find their only satisfaction in the examination by a doctor they fancy. Among old maids especially, a large number of patients come to see the doctor to be examined "very carefully" for a minor vaginal discharge or some little problem. Others

148 See Robin Morgan, "Introduction," Sisterhood is Powerful: An Anthology of Writings from the Women's Liberation Movement (1970), especially xxvi-xxvii. See also Campbell, "A Feminist Sexual Politics: Now You See It, Now You Don't"; Rachel DuPlessis and Ann Snitow, eds., The Feminist Memoir Project; Sandra Bartky, "Feminine Masochism and the Politics of Personal Transformation." In this last piece, which originally appeared in 1984, Bartky both uses, and examines, the language of ethical self-scrutiny, of "criticism and self-criticism."

149 The Onion, February 19, 2003. Actually, this is not entirely a caricature: see Nina Power's analysis of Jessica Valenti's Full Frontal Feminism: A Young Woman's Guide to Why Feminism Matters, in One Dimensional Woman, 35.

150 "Il y a dans toutes ces affirmations une vérité. Seulement les conduites que l'on dénonce ne sont pas dictées à la femme par ses hormones ni préfigurées dans les cases de son cerveau: elles sont indiquées en creux par sa situation" ( $D S$ 2:483). 
suffer from a cancer phobia, or fears of infection (from a toilet) and these phobias give them a pretext for being examined.

He cites among others the two following cases:

B.V., a rich old maid of forty-three, goes to see a doctor once a month, after her period, demanding a very careful exam because she thought something was wrong. Each month she picks a new doctor and each time plays out the same scene. The doctor asks her to undress and lie down on the table or the couch. She refuses, saying she is too modest, that it is against nature! The doctor forces her or gently persuades her, she undresses, finally, explaining that she is a virgin and that he must be careful not to hurt her. He promises to give her a rectal exam. Often the orgasm appears as soon as the examination begins; it is repeated, and intensifies, during the rectal exam. She always goes under a false name and pays immediately.... She admits that she has played with the idea of being raped by a doctor....

Mrs. L.M., thirty-eight, married, tells me she is completely sexually numb with her husband. She comes to be analyzed. Only after two sessions does she admit to having a lover. But he does not succeed in bringing her to orgasm. She only has them when being examined by a gynecologist. (Her father was a gynecologist!) Nearly every second or third session, she is driven to go to a doctor and ask for an examination. Sometimes she asks for a treatment, and those are her happiest times. The last time, a gynecologist gave her a long massage because of a supposedly prolapsed uterus. Every massage led to many orgasms. She explains her passion for these examinations by the first one she ever had, which brought on the first orgasm of her life....

A woman can easily imagine that the man to whom she has bared herself has been impressed by her physical charms or her beautiful soul, and so in pathological cases she persuades herself that the priest or the doctor is in love with her. Even if she is normal, she gets the impression that a subtle connection has been forged between him and her; she revels in respectful obedience; sometimes, however, she draws from this a confidence that helps her to accept her life. ${ }^{151}$

$15^{1}$ "[L]es trois quarts des hommes que persécutent les érotomanes sont des médecins; dénuder son corps devant un homme représente pour maintes femmes un grand plaisir exhibitionniste. 
What are we to make of this? Is it simply a feature of the encyclopedic nature of The Second Sex, its "nothing human is alien to me" quality, which, I am arguing, interrupts and problematizes any idea that a unitary, naturalized account of "woman" can be given? It may be more significant that the women who love doctors too much are highly respectable bourgeoises, and that these examples come in the chapter on "La vie de société" (Parshley translates this as "social life," but "société" here refers more specifically an uppercrust form of life, as in our phrase "high society"). It is as if to say: see, your nice normal banal "bonheur" has this kind of rot at its root, drives women to this kind of insanity. Beauvoir didn't hate women, but she sure didn't like ladies very much. Those

Je connais quelques femmes, dit Stekel, qui trouvent leur seule satisfaction dans l'examen par un médecin qui leur est sympathique. C'est particulièrement parmi les vieilles filles qu'on trouve un grand nombre de malades qui viennent voir le médecin pour se faire examiner 'très soigneusement' pour des pertes sans importance ou pour un trouble quelconque. D'autres souffrent de la phobie du cancer ou des infections (par les W.-C.) et ces phobies leur donnent un prétexte à se faire examiner.

Il cite entre autres les deux cas suivants:

Une vielle fille, B.V. ...., quarante-trois ans, riche, va voir un médecin une fois par mois, après ses règles, en exigeant un examen très soigneux parce qu'elle croyait que quelque chose n'allait pas. Elle change chaque fois de médecin et joue chaque fois la même comédie. Le médecin lui demande de se déshabiller et de se coucher sur la table ou le divan. Elle s'y refuse en disant qu'elle est trop pudique, qu'elle ne peut pas faire une chose pareille, que c'est contre la nature! Le médecin la force ou la persuade doucement, elle se déshabille enfin, lui expliquant qu'elle est vierge et qu'il ne devrait pas la blesser. Il lui promet de faire un toucher rectal. Souvent l'orgasme se produit dès l'examen du médecin; il se répète, intensifié, pendant le toucher rectal. Elle se présente toujours sous un faux nom et paye de suite.... Elle avoue qu'elle a joué avec l'espoir d'être violée par un médecin....

Mme. L.M...., trente-huit ans, mariée, me dit être complètement insensible auprès de son mari. Elle vient se faire analyser. Après deux séances seulement, elle m’avoue avoir un amant. Mais il n'arrivait pas à lui faire atteindre l'orgasme. Elle n'en avait qu'en se faisant examiner par un gynécologue. (Son père était gynécologue!) Toutes les deux ou trois séances à peu près, elle était poussée par le besoin d'aller chez un médecin pour demander un examen. De temps en temps, elle demandait un traitement et c'était les époques les plus heureuses. La dernière fois, un gynécologue l'avait massée longtemps à cause d'une prétendue descente de la matrice. Chaque massage avait entraîné plusieurs orgasmes. Elle explique sa passion pour ces examens par le premier toucher qui avait provoqué le premier orgasme de sa vie....

La femme s'imagine facilement que l'homme à qui elle s'est exhibée a été impressionné par son charme physique ou la beauté de son âme et ainsi se persuade-t-elle, dans les cas pathologiques, être aimée du prêtre ou du médecin. Même si elle est normale, elle a l'impression qu'entre lui et elle existe un lien subtil; elle se complaît dans une respectueuse obéissance; parfois, d'ailleurs, elle y puise une sécurité qui l'aide à accepter sa vie" (DS 2:417-18). 
who complain that she spends too much of the book talking about her class of origin overlook the special hostility she shows toward that milieu.

Parshley does something interesting here. He cuts the passage way down and eliminates the quotations, substituting this comparatively dignified paraphrase: "Stekel reports many cases of this kind: especially old maids who come to the doctor for trifling reasons and ask for 'a very thorough examination,' or go from one gynecologist to another in search of 'massage' or 'treatment'; some frigid wives experience orgasm during medical examination only." But then off his own bat he adds a footnote:

Dr. R.L. Dickinson, famous American gynecologist, reports a number of cases of the same kind in his works (with Lura Beam) A Thousand Marriages (1931) and The Single Woman (1934). Many patients simply displayed more or less eroticism, but others made such pests of themselves that the doctor would refuse further treatment, or he would cool their ardor by hurting them intentionally. TR..$^{152}$

Words fail me, or rather, the sort of words that come to me are not very scholarly (we won't go back we'll never go back ... and for these and lots of other reasons ...). Presumably it was not part of Parshley's project (nor Stekel's) to underscore the sadism of the medical profession. I would like to think Parshley's footnote is at cross-purposes with Beauvoir's intention, but I also wish I could be clearer about what her intention was. ${ }^{153}$

The strange examples are not entirely gratuitous, however, because they connect to Beauvoir's important idea that the effects of sexual dysphoria are problematic, not just psychologically, but ethically.

The great danger our social customs create for the child, is that the mother to whom he is entrusted (bound hand and foot) is almost always an unsatisfied woman. Some would claim that women have less need of sexual satisfaction than men do; nothing is more dubious. Repressed women make bitter wives, sadistic mothers, fanatical housekeepers, unhappy, dangerous creatures. In any case, even if her desires happened to

152 The Second Sex, trans. Parshley, 547.

153 It's also hard not to wonder how Stekel, Dickinson, etc., can be so sure that the woman on their examining table is in love with them. Does she display "objective signs of pleasure," such as "viscosity"? Faugh. Think I'll postpone that Pap smear a couple more decades after all. 
be less frequent than a man's, that's no reason to find it superfluous for her to satisfy them. ${ }^{154}$

In other words, sexual frustration is a harm, and the harmed woman cannot be good.

Now that a new, complete, and accurate translation is available, it may seem otiose to keep going after Parshley, who may well have been trying to help: he may have been more aware than Beauvoir that Stekel was a sketchy authority and that some of these cases could be spurious. He also might have seen it as a writing problem that Stekel's voice comes to dominate and Beauvoir's gets lost. Around these same issues, he takes out many other quotations: a long passage about bad sex in marriage quoted from Thérèse Desqueyroux, a novel by Beauvoir's enemy Mauriac; oodles of Sophie Tolstoy; long strands of Hegel.... Insofar as I argue that the right to sexual subjectivity was part of what American feminists latched on to in The Second Sex, enough of Beauvoir's point must have been left for this message to carry. What has vanished, however, is the concreteness and plausibility of the women's misery. Oddly, it is the voices of women who are taken away (Stekel's patient, Mauriac's heroine, as well as Tolstoy's wife). The texture is changed. Yes, these chapters were redundant, but redundancy is the point. These are not isolated, odd, or pathological cases. Rather, they feed into Beauvoir's composite account of the "lived experience" of being a woman. ${ }^{155}$ In a way, this is the women's liberation poster ("for these and other reasons") writ large: it's not that every injury on the list happened to every woman, or that there is even one woman to whom all the injuries on the poster occurred, as is underscored by the fact that some of the items contradict others. Rather, the family resemblance among all these grievances becomes an

154 "Le grand danger que nos mœurs font courir à l'enfant, c'est que la mère à qui on le confie pieds et poings liés est presque toujours une femme insatisfaite" ( $D S$ 2:372).

"On prétend que la femme a moins besoin que l'homme de l'activité sexuelle: rien n'est moins sûr. Les femmes refoulées font des épouses acariâtres, des mères sadiques, des ménagères maniaques, des créatures malheureuses et dangereuses; en tout cas, ses désirs fussent-ils plus rares, ce n'est pas une raison pour trouver superflu qu'elle les satisfasse" (DS 2:426).

155 Patricia Moynaugh has repurposed Kant's idea of "exemplary validity" to explain this very well: "Beauvoir's examples interest us because they transcend themselves yet remain situated.... [She] describes experiences that have been lived by actual women, and she situates them in the moment, both in The Second Sex and in her fiction.... [E]xamples pay tribute to the utter and complete singularity of any one event or life ... yet her examples go beyond themselves. For all their specificity, which Beauvoir is intent on preserving, her examples are not contained to themselves because they expose the oppression of women in its 'endless variety and monotonous similarity"' ("Beauvoir on Lived Reality," 24). 
urgent call to collective action: not an assertion that all women are something, but a resolution to do something.

To say this another way: redundancy demonstrates mimetically that women's oppression is overdetermined. One girl gets oppressed one way; another girl escapes that but gets oppressed in a different way; one way or another, it's coming at/for you. Also: if one kind of argument doesn't convince you, another may: there's a dissertation-y amount of evidence provided here, perhaps reflecting Beauvoir's awareness that she would not be taken at her bare word. She knew this would be controversial, and it was.

Despite the new translation, it is still important to attend to the criticisms of the old one made by Moi and Fallaize because, as Moi shows, subsequent work in feminist theory (Penelope Deutscher, Tina Chanter, Judith Butler) seem to have used it, and thus misread Beauvoir. ${ }^{156}$ By changing the texture of Beauvoir's writing, Parshley's revisions make Beauvoir's discussion more homogenous than it originally was. This is not "merely" a question of style. Some commentators have worried that despite Beauvoir's announced intention of de-naturalizing and de-essentializing women's experience, the account of what "elle" (she) goes through in the course of volume 2 slips back from the experiences of women to the Experience of Woman, as a reified thing. I too would find this troubling were it so; I don't think it is; but it is truer of Parshley's Beauvoir than of Beauvoir herself.

As I see it, another kind of unhelpful flattening results from analyses that emphasize Beauvoir's utopian account of erotic possibilities, rather than her depressing catalogue of the difficulties and impasses of women's sexual situation. Disciplinary differences may account for some of this: Bergoffen, Vintges, Andrew, and Bauer approach The Second Sex by way of Beauvoir's earlier philosophical essays, whereas my first point of entry to her work is more literary. But their emphasis is also more in keeping with the trend of feminist theory to locate and foreground women's agency wherever possible, in the face of accusations about "victim feminism" or "left melancholy." Like finding "continuities" with the later work of Irigaray and Kristeva, or with the "ethic of care," this looks like an attempt to update her and underscore her continuing relevance, not just to make ourselves feel better.

But since my project is historical, it seems important to also underscore that the impetus to second-wave feminism involved pointing out over and over that the situation of woman was miserable, whatever Redbook and Mademoiselle might say, and (by multiplying examples from different genres and different walks of life) to convince women that their misery was a collective feature of

$15^{6}$ "While We Wait," 1022-25. See also Winter, "L'essentialisation de l'altérité," 77-9, 81. 
their unjust situation, not a symptom of some shameful individual neurosis. ${ }^{157}$ The claim of 1970s feminists, at least in the United States, was partly an assertion of a woman's right to be unhappy, to understand her unhappiness as unhappiness, rather than depression, maladjustment, or some other character flaw. One could take this back even farther: Lucy Stone said in 1855 that "disappointment is the lot of women," adding that "it shall be the business of my life to deepen this disappointment in every woman's heart until she bows down to it no longer." 158 And one could note that the "right to be unhappy" has been withheld particularly, though differently, from American women of color, as Tamara Beauboeuf-Lafontant shows in Behind the Mask of the Strong Black Woman.

Besides, The Second Sex does, in fact, include a strong account of women's agency - possibly too strong for some people's tastes. Beauvoir's analysis of women's "complicity" with their status as Other holds women responsible, as full human beings and ethical agents, for their own success or failure, within the horizons of possibility offered to them. This insistence motivates passages that have looked to some like they are "against women" or "blaming women." The question is, which women? A properly intersectional analysis, of the sort feminists of color and transnational feminists have been demanding, requires us to admit that women's "agency" is not always well-deployed, and that the agency of some women involves the subordination of other women. ${ }^{159}$ Such an account will include the "adaptive preferences" of women who make hard choices from among an unenviably impoverished menu of options-as Offred in The Handmaid's Tale puts it, explaining why she doesn't use the word "rape" to describe what's happening to her, “[ $t]$ here wasn't a lot of choice, but there was some, and this is what I chose." 160 It must also cover the actions some women take that do direct and serious harm to other women, whether or not it is their fully conscious intention to do so. I think Beauvoir already saw this in the 1940s.

Later parts of this book will speak more fully to claims that Beauvoir failed to understand the constraints less privileged women were under, claims I agree with Sonia Kruks and others are unfair. My observation now is simply this: one

\footnotetext{
157 See Altman, "Beyond Trashiness."

$15^{8}$ Remark made at a National Woman's Rights Convention in Cincinnati, Ohio, as quoted in Miriam Schneir, ed., Feminism: The Essential Historical Writings, 106.

159 See Kimberlé Crenshaw, "Mapping the Margins: Intersectionality, Identity Politics, and Violence Against Women of Color," and Chandra Mohanty, "Under Western Eyes: Feminist Scholarship and Colonial Discourse." I'll discuss this more fully in later chapters.

16o Margaret Atwood, The Handmaid's Tale, 94. See also Serene Khader, Adaptive Preferences and Women's Empowerment.
} 
especially productive feature of Beauvoir's approach is her recognition that the question of "agency" is not the only question, and does not exhaust feminist ethical and political analysis: remember that she says, "[t]his fall [from freedom to facticity] is a moral failing if the subject consents to it; if it is inflicted on the subject, it takes the shape of a frustration and an oppression; $e i-$ ther way, it is an absolute evil."161 There is something refreshing about the reminder that identifying an evil thing, and working to get rid of it, is actually more important than figuring out whose fault it was and how it came about. ${ }^{162}$ It's not that agency doesn't matter, it's that the concept of harm is broader than the question of agency, and we should not be sidetracked into taking the part for the whole.

Truth to tell, I find it hard to see how one could speak of a feminist ethics, let alone a feminist politics, without some conception of women as agents making choices, however constrained those choices may sometimes be; and it must be possible for women to make bad ethical choices if it possible for women to make good ones. The distinction between ethics and politics was one Beauvoir did not make, either before or after she began to call herself a feminist. I see no good reason to make that distinction, either. As Chris Cuomo has remarked, "feminism is an ethical system." 163

If we accept all this, we will next have to accept the need to specify a content to our ethical judgment, and take responsibility for that, rather than quasidemocratically falling back on "agency" as if that were the ultimate feminist good. For instance, we might say that, on a collective level, women's subordination was connected to the commodification of sexuality whether through marriage or through sex slavery/trafficking or through anything in between. Women may feel powerful through sexual performance and exchange and yet not actually be powerful (they could be wrong about it). Or, some individual women might genuinely be "empowered" through complicity, but the individual agency of some women is detrimental to other women and to the interests of

161 Emphasis added. "Chaque fois que la transcendance retombe en immanence il y a dégradation de l'existence en 'en soi,' de la liberté en facticité; cette chute est une faute morale si elle est consentie par le sujet; si elle lui est infligée, elle prend la figure d'une frustration et d'une oppression; elle est dans les deux cas un mal absolu" (DS 1:31).

162 As she said in another context, "[t]o look for the reasons why one should not stamp on a man's face is to accept stamping on his face." [Chercher les raisons pour lesquelles il ne faut pas marcher sur la figure d'un homme, c'est accepter qu'on lui marche sur la figure (FCh 101, FCirc 77, translation modified).]

163 NWSA Conference, Program Administration and Development Workshop, November 12, 2009, Atlanta, Georgia. 
women as a class. ${ }^{164}$ What ethical content we specify is left open, but, once we specify it, we will have to admit that we disagree, say what our values are, and acknowledge that, as Beauvoir says in Pour une morale de l'ambiguité (The Ethics of Ambiguity) and elsewhere, to work toward one good may damage another. ${ }^{165}$

Like it or not, the root of Beauvoir's claim for women's agency was in the existentialist account of freedom. This account has usually been labelled "Sartrean," and Sartre has become so unpopular now within both feminism and philosophy that it may be hard to remember his value for an earlier generation of feminist ethicists (like Sandra Bartky and Iris Marion Young), not to mention the successful political mobilizations that have been taken up in his name. ${ }^{166}$ But Foucault scholar and queer theorist Didier Eribon takes his cue from Sartre; ${ }^{167}$ and the young British activist (and philosopher) Nina Power, who came to public attention around 2011 as a blogger for student street protests, startled me in a talk at Oxford by saying nonchalantly, as if it were a matter of course, "well, I'm an existentialist..." It's almost enough to make one stop believing in the idea of intellectual history, or at least the idea of "generations."

Sartre's own writing certainly deserves the feminist critiques it has attracted. But the fact that in academic circles it has become slightly embarrassing to use words like "freedom" and "liberation" at all strikes me as seriously problematic. Do we say "agency" now simply to avoid saying "freedom," as we say "the body" or "the erotic" to avoid saying "fucking," let alone "frigidity"? (To avoid being associated with braless bead-wearing hairy-legged viragos who actually meant it when they said they didn't want to get married, that marriage was a trap, that the only way to win the "Beauty Myth" game was to refuse to play?) Well, yes, it's a fairly terrifying idea, freedom. As the existentialists said.

164 See Altman and Kerry Pannell, "Policy Gaps and Theory Gaps: Women and Migrant Domestic Labor."

165 See Kruks, "Introduction to "Moral Idealism and Political Realism," and Simone de Beauvoir and The Politics of Ambiguity. I'll discuss Pour une morale de l'ambiguité in more detail in chapter 3 .

166 Bartky, for instance, in explaining that "feminist consciousness, in large measure, is an anguished consciousness," quotes L'être et le néant: "It is on a day that we can conceive of a different state of affairs that a new light falls on our troubles and we decide they are unbearable" ("Toward a Phenomenology of Feminist Consciousness," 14).

167 Eribon's collection Papiers d'identité takes its epigraph from Sartre: "Limportant n'est pas ce qu'on fait de nous, mais ce que nous faisons nous-même de ce qu'on a fait de nous" (What matters isn't what they make of us, but what we make of what they make of us). 
Once we overcome our anxiety about genre- there's no reason good philosophy cannot be written about bad sex-we might note without concern that popular sexologists and even marriage manuals from the 1950s and 196os refer back to Beauvoir. (I find this less surprising now that I've seen Judith Coffin's excellent article documenting how the reception of Beauvoir's work was intertwined with the reception of Kinsey's.)

Anne Koedt does not mention The Second Sex. But in 1964, a little book called The Sexually Responsive Woman, by Phyllis and Eberhard Kronhausen, was published by the slightly disreputable Grove Press, with an approving (though brief) preface by Beauvoir. ${ }^{168}$ Perhaps it is fanciful to see this title as a deliberate refutation of Caprio's Sexually [In]Adequate Female: the word "responsive" clearly places it as one of a spate of books popularizing and domesticating the research of Masters and Johnson, which was published as Human Sexual Response (Grove had quite a line-up of these). ${ }^{169}$ The authors, a married couple and both therapists, do set out in some detail the Masters and Johnson findings, which (by the way) corroborated through measurement what Beauvoir had said in The Second Sex about the timing of woman's arousal. They are very critical of Freud and psychoanalysis, very much pro-orgasm, and very clear about the sorts of stimulation that are effective in bringing it about. Most of the book, however, is given over to the life histories of five women chosen as representative: they are called "The More-Than-Average-Housewife," "The Married Lesbian," "The Doctor's Wife," "The Sexual Sophisticate," and "The Female Psychoanalyst." Certainly, as with Stekel, someone could read and buy it for the spicy stories (this was what kept Grove in business), and the chapter titled "The Struggle for Orgasm" is not at all political, but otherwise there is little for a feminist of any era to object to. I find it interesting that Beauvoir continued to support this kind of work. I don't know what position she would have taken in the "sex wars" of the 1980 s and 199os, but we can be pretty sure she wouldn't have taken the position that they were irrelevant.

So is The Second Sex a self-help book? Hardly. For one thing, it doesn't offer any help. As I said earlier, there's no use of psychoanalysis as a therapeutic discourse (it is mainly descriptive, occasionally explanatory), nor does she make

168 Phyllis Kronhausen and Eberhard Kronhausen, The Sexually Responsive Woman. Flap copy tells us they are also "authors of the widely read and much-discussed Pornography and the Law."

169 See Paul Robinson, The Modernization of Sex: Havelock Ellis, Alfred Kinsey, William Masters and Virginia Johnson. 
any allusion to possible therapeutic uses of existentialist philosophy. And she appears to have had some suspicion of the self-help genre herself.

Americans today, who are quite respectful of the institution of marriage and also individualists, are redoubling their efforts to integrate sexuality with wedded life. Each year a great many works are published about starting married life, designed to teach spouses to adapt to one other, and especially to teach the man how to create a happy harmony with his wife. Psychoanalysts and doctors take the role of "marriage counselors," and it is acknowledged that, yes, the wife too has a right to pleasure, and the man should be acquainted with the best techniques to arrange it for her. But we have seen that sexual success is not just a matter of technique. Even if the young man knows by heart a hundred manuals like What Every Husband Should Know, The Secret of Conjugal Bliss, and Love Without Fear, he still cannot be sure of getting his new wife to love him. For she reacts to the situation as a whole. And traditional marriage hardly creates the most conducive conditions for female eroticism to awake and bloom. ${ }^{170}$

To get from bad sex to good sex will require more than an earnest "good faith" effort: institutions will have to change.

And in fact Beauvoir's view of good sex is very demanding. Good sex must be autonomous, spontaneous, free-Bergoffen is right to quote the bit about the "instant." But the further implication is that good sex will also be episodic, that there is no way to stabilize it as part of a permanent arrangement. Couples who've been together for a long time, she says, tend to fall into something resembling incest or mutual masturbation; fantasizing about one person while you're in bed with another, she calls a "comédie" (playacting); "infliger une

170 "[L]es Américains d'aujourd'hui, qui sont à la fois respectueux de l'institution conjugale et individualistes, multiplient les efforts d'intégration de la sexualité au mariage. Chaque année paraissent quantité d'ouvrages d'initiation à la vie conjugale destinés à enseigner aux époux à s'adapter l'un à l'autre, et singulièrement à enseigner à l'homme comment créer avec la femme une heureuse harmonie. Des psychanalystes, des médecins jouent le rôle de 'conseillers conjugaux'; il est admis que la femme a, elle aussi, droit au plaisir et que l'homme doit connaître les techniques susceptibles de le lui procurer. Mais on a vu que la réussite sexuelle n'est pas seulement une affaire de technique. Le jeune homme eût-il appris par cœur vingt manuels tels que Ce que tout mari doit savoir, Le secret du bonheur conjugal, L'amour sans peur, il n'est pas certain qu'il saura pour autant se faire aimer de sa nouvelle épouse. C'est à l'ensemble de la situation psychologique que celle-ci réagit. Et le mariage traditionnel est loin de créer les conditions les plus favorables à l'éveil et à l'épanouissement de l'érotisme féminin" ( $D S$ 2:244). 
jouissance" can be a power play; being deliberately, almost professionally, "good at" giving another person pleasure, as Elisabeth's boy-toy Guimiot does in Linvitée, is faintly disgusting; another form of ersatz sexuality is the pursuit of sexual experience in the absence of genuine and deep desire (she says American girls are particularly prone to this, but in Les mandarins something very similar is attributed to Nadine). ${ }^{171}$ So it seems unlikely that she would have thought very highly of the "sensate focus" exercises recommended by Masters and Johnson, or of the books on "improving sexual communication" that filled the shelves and tables of the Barnes and Noble in its heyday. Perversely, all these approaches are too conscious, too deliberate and intentional, not truly intersubjective. Good sex cannot be a project. So where Beauvoir's statement of the problems draws on and in some ways resembles the sexological sources foregrounded by self-help (she even uses some Kinsey statistics about the timing of orgasm), she wouldn't have liked any of their answers. As Vintges notes, "when a young woman came to see her and asked advice, Beauvoir told her to think about things other than herself, and to read rather than to talk."172

Like much else, this goes back to the distinction between "happy" and "free." It seems to me that Beauvoir's view of "happiness" owes a lot to the trip to the United States she recorded in L'Amérique au jour le jour 1947 (America Day by Day 1947), which overlapped with the writing of The Second Sex. I agree with Edward Fullbrook that people should pay more attention to that book, which he says "stands in relation to The Second Sex, rather like Darwin's The Voyage of the Beagle does to The Origin of Species." 173 A lucid, but not unloving, critique of American popular culture, at the height of McCarthyism and the Jim Crow South, it could be compared to William Whyte's The Organization Man in some ways, to Adorno's Minima Moralia in others. Beauvoir talks there about "bookstores where men and women buy books with promising titles: The Secret of Happiness, Happiness in Five Lessons," and also about the "mystification" practiced by radio therapists, and the general tendency of Americans to see nonconforming individuals as "cases." ${ }^{174}$ With particular reference to returning GIs and the treatment of what's now called "post-traumatic stress syndrome," she observes:

Psychoanalysis is a vast enterprise of social recuperation; its sole aim is to enable each citizen to take up a useful place in society.... To be

\footnotetext{
171 DS 2:256-58, 177; L'invitée, 107-10; Les mandarins 2:174-75.

172 Vintges, Philosophy as Passion, go.

173 Fullbrook, "Patriarchy's History of Ideas," 125.

174 L'Amérique au jour le jour 1947 (hereinafter AJ), 90-1.
} 
well-adapted, here, means in truth to hand in one's resignation from oneself; to be happy is to persist stubbornly in blinding oneself. Many things would change for Americans if they could only admit that there is unhappiness on earth, and that unhappiness is not a priori a crime. ${ }^{175}$

What's interesting is that while Beauvoir dismisses "the pursuit of happiness," which can result from and/or lead to false consciousness, bad faith, complicity, etc., she does not dismiss the question of unhappiness, which results from objective conditions of unfreedom, and is destructive of both the self and others. Unhappiness presumes the possibility of happiness, which lies somewhere over the horizon: one cannot and should not will it into existence, any more than one should "infliger une jouissance." Nonetheless, as an American product of that same vintage insisted, attention must be paid.

These ideas seem unlikely to sell any mugs or t-shirts for the Feminist Majority. But they resonate with Arlie Hochshild's The Managed Heart, Barbara Ehrenreich's Bright-Sided: How the Relentless Promotion of Positive Thinking Has Undermined America and, in a different way, Sara Ahmed's Promise of Happiness, which warns particularly of the ways "happiness is used to justify oppression." ${ }^{176}$

Where does this leave psychoanalysis? One irony of teaching Beauvoir now is that it may be the first exposure to Freud students have ever had-whether because feminist critiques have been successful, or for more depressing reasons. It feels slightly insane to have to introduce students to the idea of "penis envy" in order to show them what nonsense it is: their faces show pretty clearly that they can figure that out for themselves. The smug determinists feminism must now confront are not psychoanalysts but neuroscientists and their pillpushing accomplices.

175 "La psychanalyse est une vaste entreprise de récupération sociale; son seul but c'est de permettre à chaque citoyen de reprendre une place utile dans la société.... On comprend bien qu'après avoir respiré pendant toute leur jeunesse l'optimisme américain, après avoir vécu dans un pays qui nie l'existence du mal, ces jeunes gens ont étés bouleversés par une brusque confrontation avec le monde en guerre, et leur expérience ne s'intègre plus au système dans lequel il leur faut à nouveau se situer. Ceux qui ont le courage de continuer à croire en cette expérience représentent une force neuve; mais beaucoup se sentent simplement perdus. On les regardera comme guéris quand ils auront perdu la conscience d'être perdus. S'adapter, ici, c'est en vérité se démettre de soi-même; être heureux, c'est savoir s'aveugler avec entêtement. Beaucoup de choses seraient changées chez les Américains s'ils voulaient bien admettre qu'il y a du malheur sur terre et que le malheur n'est pas a priori un crime" (AJ 93).

176 Sara Ahmed, The Promise of Happiness, 2. Ahmed starts from Beauvoir, but also takes aim at what she sees as a recent "happiness turn." 
But I still think it's worth engaging with the part of Beauvoir's uptake of Freud that was not just critique. An examination of the issues of Les Temps Modernes around the time she was working on, and serially publishing, The Second Sex, shows a more profound and more eclectic engagement with his work than has previously been assumed. ${ }^{177}$ And I find it a promising development that European psychoanalysts seem to have become interested in Beauvoir, and especially that a number of them seem to be recognizing the value of a feminist psychoanalysis that would not be Lacanian. ${ }^{178}$ Élisabeth Roudinesco notes that, toward the end of her life, Beauvoir expressed a wish that she had written a study of psychoanalysis from woman's perspective; Roudinesco points out that actually, she had already done so. Those who want "les apports de la psychanalyse" without the gender normativity may find some cues in Beauvoir's work, even now.

It's not usually noted that Anne, the heroine of Les mandarins, is working on a book-when another character asks her if she too is a writer, she answers, "Thank God, no!"179 And commentators have sometimes criticized Beauvoir for not creating a model Woman Writer in this character with whom she shares so much else of her life. Nonetheless there are a few points where we see Anne

177 For instance, in issue 32 (May 1948), the first extract from what would become Le deuxième sexe appears under the title "La femme et les mythes," described in a footnote as "extrait d'un ouvrage à paraître sur la situation de la femme." The same issue also includes a long extract by Freud himself, "Moïse et son peuple," translated by Annie Merma-it seems to be from the third part of Moses and Monotheism. What interests me is the unsigned introductory note, which contextualizes it and ends with the following paragraph:

As always, one might find some of the interpretations Freud gives to be narrow. Rather than explaining human conflict by sexual conflict, one might reintegrate the hatred of the father to human aggression. The study by Simone de Beauvoir, published in this issue, shows precisely, on certain points, how sexuality is taken up in human conflicts which do not go beyond it ["dépassent" translates the Hegelian term "Aufhebung"] but rather, so to speak, set it in motion. However, these very conceptions were not foreign to Freud and in any case are only made possible by his work, to which, in publishing these texts, we wish to pay homage." [Comme toujours, on peut trouver ici que certaines interprétations données par Freud sont étroites. Au lieu d'expliquer le conflit humain par le conflit sexuel, on pourrait réintégrer la haine du père à l'agressivité humaine. L'étude de Simone de Beauvoir publiée dans ce même numéro montre justement, sur certains points, comment la sexualité est reprise dans des conflits humains qui ne la dépassent pas, mais qui, pour ainsi dire, l'animent. Cependant, ces conceptions mêmes ne sont pas étrangères à Freud et, en tout cas, elles n'ont été rendues possibles que par son œuvre, à laquelle, en publiant ces textes, nous voudrions rendre hommage.]

178 See Élisabeth Roudinesco, Juliet Mitchell, Jacqueline Rose, and other contributors to the excellent Simone de Beauvoir et la psychanalyse, edited by Pierre Bras and Michel Kail.

179 Les mandarins, $5^{2}$. 
working on "mon livre," which is an attempt to bring together the insights of Marxism and psychoanalysis. Perhaps the book she was working on was The Second Sex. Or perhaps (in spite of the energy expended on the question in the 1970 and 1980s) that book remains to be written.

\section{Last Thoughts}

So what have we learned from the frigid woman, that can still matter to us today?

First, that women's sexual and bodily unhappiness should not be disregarded. (Date rape, anorexia.)

Second: that we should be suspicious of the promises of therapy and selfhelp, even as we recognize that we cannot hope to extricate feminism from them. (Oprah, Glamour magazine.) ${ }^{180}$ We should work with this rather than isolating ourselves. Because as long as women are perceived as having to choose between their emancipation as human subjects on the one hand, and the possibility of sexual and personal happiness on the other, feminism cannot occur, as we who try to teach it to the young are well aware.

In her youth, Simone de Beauvoir saw herself as facing this choice, between her independent, intellectual self and the possibility of "bonheur," because marriage to her bourgeois cousin Jacques and a future life as a "femme d'intérieur" would have meant sacrificing literally everything else she cared about. Later she met Sartre and discovered (she says) that she could have both. Vintges suggests that Beauvoir's contribution to ethics is partly her creation of her own life as "exemplary," her description of an "art of living," and I think this is right; but some who have taken this too literally ("Simone de Beauvoir, Live like Her")—have taken it as if it were self-help, in fact-have ended up disappointed in her, or in Sartre (and his New Left avatars), or in themselves. ${ }^{181}$ It might make more sense to look at what she says about this "choice" on the level of theory, which I think is roughly the following: the opposition is false from the start, bourgeois happiness is a sell, because oppressed sex is bad sex.

Third: you can use a bad tool to do a good task.

Michèle Le Dœuff suggested that Simone de Beauvoir had a "genius for the inappropriate," meaning that she started from a philosophical viewpoint (Sartre's solipsistic version of existentialism) that was poorly suited to what she

180 See Rapping, The Culture of Recovery.

181 See for instance Nancy Miller, Bequest and Betrayal: Memoirs of a Parent's Death. 
wanted to make of it (feminism). ${ }^{182}$ At the very least, she had an unusual willingness to make use of whatever came to hand. I do think it's reasonable to hold people accountable when they use problematic discourses uncritically, e.g. "Lacan dit," as though the mere citation of an authoritative name put an end to thought. But I hope feminism has set aside the task of purifying our own discourse (or policing the language of other feminists) for residues. Indeed, for a text to be political in any meaningful sense it must engage with, be embedded in, concrete and substantial circumstance. We all have to stand somewhere.

182 Hipparchia's Choice, 55 . 